\title{
Glaciological advances made with interferometric synthetic aperture radar
}

\author{
Ian JOUGHIN, ${ }^{1}$ Ben E. SMITH, ${ }^{1}$ Waleed ABDALATI ${ }^{2}$ \\ ${ }^{1}$ Polar Science Center, Applied Physics Laboratory, University of Washington, 1013 NE 40th Street, Seattle, \\ Washington 98105-6698, USA \\ E-mail: ian@apl.washington.edu \\ ${ }^{2}$ Earth Science and Observation Center, Cooperative Institute for Research in Environmental Sciences, and \\ Department of Geography, University of Colorado, Boulder, Colorado 80309, USA
}

\begin{abstract}
Spaceborne interferometric synthetic aperture radar (InSAR) techniques for measuring ice flow velocity and topography have developed rapidly over the last decade and a half, revolutionizing the study of ice dynamics. Spaceborne interferometry has contributed to major progress in many areas of glaciological study by: providing the first comprehensive measurements of ice-stream flow velocity over the major outlets of Greenland and Antarctica; revealing that ice-stream and outlet-glacier flow can change rapidly (months to years); improving understanding of several ice-sheet and ice-shelf processes; providing velocity for flux-gate based mass-balance assessment; mapping flow of mountain glaciers; and capturing the geomorphic traces of past ice flow. We review the basic technique development, the measurement characteristics, and the extensive set of results yielded by these measurements.
\end{abstract}

\section{INTRODUCTION}

By definition, glaciers flow. Since the earliest scientific studies of glaciers (e.g. Agassiz, 1967), glaciologists have travelled to remote locations to measure the surface velocity and elevation of glaciers and ice sheets in an attempt to understand the internal stresses and strains related to gravitydriven flow. While the advent of the Global Positioning System (GPS) has made field observation easier, timeconsuming and expensive field seasons are still required to monitor a glacier in situ at a few dozen points. From early in the satellite era, cameras have photographed glaciers and ice sheets from space, and such images can provide denser (thousands rather than dozens of points) velocity measurements (e.g. Lucchitta and Ferguson, 1986). Unfortunately, such measurements are limited to the parts of the ice sheet or glacier where there are features visible for tracking and to the times when the surface is not obscured by clouds nor cloaked in darkness. Thus, despite the geodetic and imaging advances provided by satellites, glaciology remained a 'data-poor' discipline in the early 1990s, with even the well-studied Whillans Ice Stream (former Ice Stream B) characterized largely by sketch maps, supplemented by a few dozen sparse measurements of velocity (Whillans and Van der Veen, 1993).

Goldstein and others (1993) made a revolutionary advance in glaciological methods when they observed icestream motion in Antarctica using interferometric synthetic aperture radar (InSAR) (Fig. 1). Soon after, European Remotesensing Satellite-1 (ERS-1) data were used to observe displacement along the western flank of the Greenland ice sheet (Joughin and others, 1995; Rignot and others, 1995). While the characteristics of individual InSAR missions limit their ability to make measurements in some areas, in principle the technique can provide day-or-night measurements over an entire ice sheet or glacier under all weather conditions. Since this technique was first introduced, InSAR velocity and elevation data have facilitated numerous other glaciological advances, which are reviewed throughout this paper. We begin with an overview of the basic methods, followed by a description of several areas of study in which InSAR data have contributed to fundamental advances. We conclude with a look forward to the new InSAR observations that we can expect over the next decade.

\section{InSAR METHODS}

Interferometric methods were first developed for measuring surface topography using airborne systems (Graham, 1974; Zebker and Goldstein, 1986). Early development of spaceborne topographic mapping with InSAR was based on data from the Shuttle Imaging Radar missions (Gabriel and Goldstein, 1988) and Seasat (Li and Goldstein, 1990). Later, Gabriel and others (1989) demonstrated that, using a pair of images acquired at different times, InSAR could be used to measure millimeter-scale deformation of the Earth's surface. Following the 1991 launch of ERS-1 SAR by the European Space Agency (ESA), Goldstein and others (1993) successfully showed that the same technique could be applied to ice sheets and glaciers. Although InSAR has been applied to a wide variety of processes involving surface deformation and topography, here we focus on its application to glaciers and ice sheets. Several review papers cover developments in the many other fields where InSAR is often used and provide more detailed descriptions of InSAR methods (e.g. Massonnet and Feigl, 1998; Rosen and others, 2000; Rott, 2009).

A radar interferometer images the ground using two antennas located at points $S_{1}$ and $S_{2}$, separated by a baseline, B, with components normal to, and parallel to, the radar look direction ( $B_{n}$ and $B_{p} ;$ Fig. 2). Interferometric methods use the difference in ranges (line-of-sight distances), $\Delta$, from each antenna to the point being imaged on the ground. When two distinct antennas are used and the data are collected simultaneously, this is referred to as single-pass InSAR, and $\Delta$ is sensitive to the elevation of the radar-illuminated point, with topographic sensitivity approximately proportional to $B_{n}$. With repeat-pass interferometry, a point on the ground is imaged at different times, either with the same or different antennas so that if the 

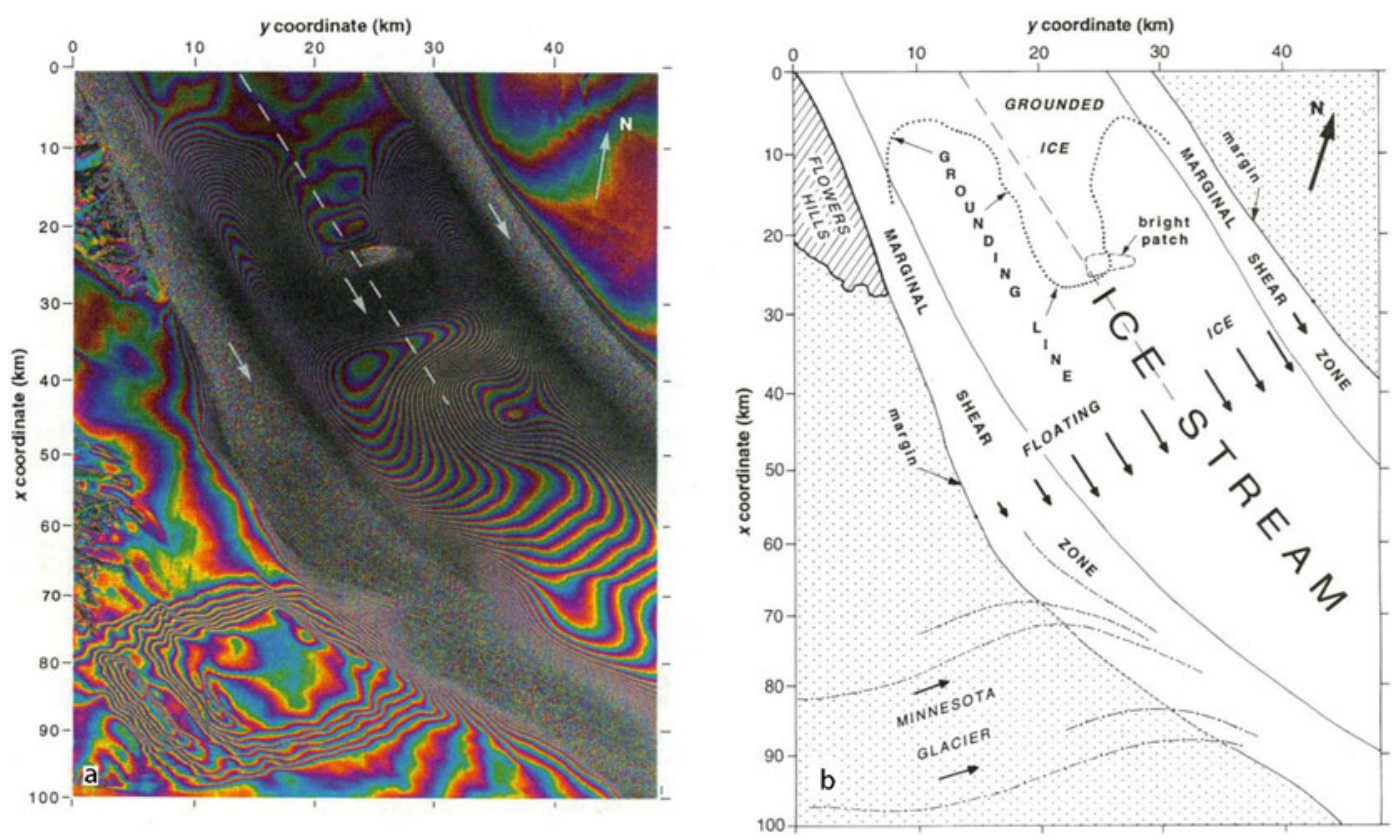

Fig. 1. (a) ERS-1 SAR interferogram and (b) corresponding map for Rutford Ice Stream, Antarctica, from Goldstein and others (1993). Reproduced with permission of American Association for the Advancement of Science via Copyright Clearance Center.

surface is moving, any displacement of the point along radar-line-of sight produces an additional motion-dependent contribution to $\Delta$

\subsection{Interferometric phase}

InSAR relies on the ability to measure $\Delta$ accurately. The phase of an individual complex SAR image is proportional to the line-of-sight range from the antenna to the ground. Thus, with a repeat-pass interferometric pair of images at radar wavelength, $\lambda$, the product of the first image and the complex conjugate of the second yields an interferogram with phase $\phi=4 \pi \Delta / \lambda$. This phase, however, is only known modulo $2 \pi$, which gives rise to the fringes visible in raw interferograms (e.g. Fig. 1a). Where the fringes are well defined, a process known as phase unwrapping can be used to remove the modulo- $2 \pi$ ambiguity (e.g. Goldstein and others, 1988). In areas with large strain rates or steep topography, the interferometric fringes can be tightly spaced or even aliased such that phase unwrapping is not possible (e.g. the shear margin in Fig. 1).

The images in an interferometric pair must remain sufficiently correlated (coherent) to provide usable phase information. As the baseline increases, decorrelation is introduced, creating phase noise, and, once the baseline exceeds a critical length, the decorrelation yields completely random phases. Temporal decorrelation occurs when the relative positions of individual scatterers within a pixel change on the scale of half of the wavelength (typically 1$12 \mathrm{~cm}$ ) in the interval between when the two images are acquired, in some cases leading to complete data loss. For example, the waves on the ocean surface change on subsecond timescale, causing complete decorrelation in images separated by seconds or more. As a result, images of ocean surfaces that are separated by seconds or more are of no interferometric value. On glacial ice, however, coherence can be maintained for days to months as the scatterers move large absolute distances (many meters), as long as they undergo only small relative changes (i.e. intra-pixel strains are small relative to a wavelength). Because the radar signal often penetrates several meters into the firn, the near-surface rearrangement of snow grains during compaction is often the dominant source of temporal decorrelation of ice-sheet images, especially in high-accumulation regions where compaction is more rapid. High-accumulation areas also tend to have low backscatter so that low signal-to-noise ratios may be an additional source of decorrelation in these regions (Hoen and Zebker, 2000).

A repeat-pass interferogram is sensitive to both the motion and the topography of a glacier's surface. When the motion is uniform, differencing two interferograms cancels the

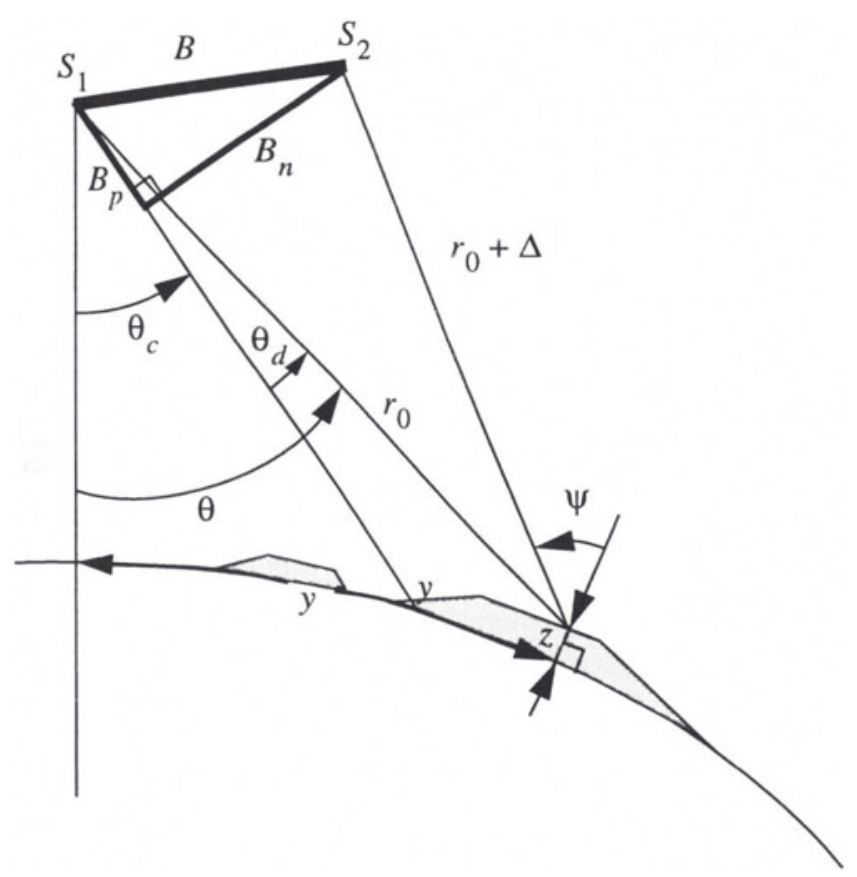

Fig. 2. InSAR geometry (Joughin and others, 1996b). 
identical motion-dependent phases so that the topographic signal can be retrieved to produce a digital elevation model (DEM) (Joughin and others, 1996c; Kwok and Fahnestock, 1996), although the large penetration depths mean that the measured surface may lie at spatially varying depth several meters below the snow-air interface (Rignot and others, 2001b). This DEM or, as is often the case, an independent DEM is then used to determine and remove the topographydependent phase from the repeat-pass interferogram to recover the motion-dependent phase used for velocity estimation. With a single-pass interferogram, however, the phase is sensitive to only topography since no motion is observed because the constituent images are acquired simultaneously. While most space-based SARs cannot be used for single-pass interferometry, a notable exception was when the Shuttle Radar Topography Mission (SRTM) flew two antennas simultaneously on the space shuttle in February 2000 to create a map of the land surface topography for regions between $60^{\circ} \mathrm{N}$ and $56^{\circ} \mathrm{S}$ (Farr and others, 2007).

A single interferogram is sensitive to displacement only in the radar line-of-sight direction, which includes both horizontal and vertical components (Fig. 2). Ideally, observations from three (or more) look directions are needed to resolve the full three-dimensional (3-D) velocity vector. Most SARs image with a north-looking geometry, so observations are only possible from two significantly different directions (ascending and descending orbits). If glacier flow is, or is at least assumed to be, surface-parallel, however, then the velocity vector lies in the plane locally tangent to the surface so that a solution can be derived from observations in two directions and knowledge of the surface slope (Joughin and others, 1998; Mattar and others, 1998; Mohr and others, 1998). While this method has been widely applied, it ignores the non-surface-parallel submergence/emergence velocity and other vertical displacements (e.g. those due to subglacial water movement), which in some cases can lead to substantial errors (Reeh and others, 1999).

Accurate estimation of topography or motion from an interferogram requires a level of baseline accuracy better than that to which the spacecraft's orbital trajectory is known. Even if the orbital path was known perfectly, phase unwrapping provides only a relative result, uncertain to within what effectively amounts to an unknown constant of integration after the unwrapping procedure. Thus, control points (points of known elevation and velocity) typically are necessary to solve for the baseline. While there are only a few parameters to solve for, technically requiring only the same number of control points as unknowns, better results may be achieved with a least-squares solution using a larger number of control points well distributed through the area covered by the interferogram (Joughin and others, 1996b). In addition to errors from decorrelation and baseline uncertainty, interferometric estimates are subject to errors from range delays produced by variations in the troposphere (Goldstein, 1995) and ionosphere (Gray and others, 2000).

\subsection{Speckle tracking}

Even when interferometric coherence is maintained, fast motion and high strain rates often cause strong aliasing of the phase, making it impossible to produce phase-based estimates, especially when the repeat period is long. In these cases, cross-correlation of complex or detectedamplitude image patches, similar to optical feature tracking, produces estimates of $\Delta$, albeit with less accuracy and poorer (hundreds vs tens of meters) spatial resolution than phase estimates. Although this method benefits from distinct features visible in the imagery, the matching is primarily based on the narrow ( $<1$ pixel) cross-correlation function of the speckle patterns (normally a source of noise) in the radar images, which allows sub-pixel ( $\sim 0.1$ pixel) determination of displacements. Since it does not rely on the presence of distinct features, speckle tracking works even in the most featureless regions in the middle of ice sheets, as long as the radar speckle remains correlated. Another benefit of speckle tracking is that motion information is also obtained in the along-track (azimuth) direction, making it possible to estimate both components of horizontal motion from a single pair. This technique was first applied to RADARSAT data in Antarctica (Gray and others, 1998) and soon after to L-band repeat-pass Shuttle Imaging Radar from Glaciar Moreno, Argentina (Michel and Rignot, 1999). The long repeat periods of RADARSAT and the Advanced Land Observing Satellite (ALOS) tend to make phase measurements difficult because large displacements frequently alias the phase, even though the underlying correlation is maintained. In these cases, the longer observation intervals can be beneficial for speckle tracking since they yield more displacement signal relative to the noise inherent in the cross-correlation process used to determine the offsets. As a result, for instruments with long repeat periods (e.g. RADARSAT and ALOS), speckle tracking is often the preferred method (e.g. Rignot and others, 2008b; Joughin and others, 2010a).

When the radar speckle patterns are coherent, speckletracking provides a distinct advantage over optical featuretracking because it provides estimates in even the most featureless areas. In image pairs where the speckle has completely decorrelated, however, distinct features (e.g. crevasses) can still be tracked in SAR image pairs using the same methods as applied to optical imagery (Luckman and others, 2003; de Lange and others, 2007). In addition to the ice sheets, both SAR feature-tracking and speckle-tracking methods have been applied to glaciers in Svalbard (Strozzi and others, 2002), the Canadian Arctic (Short and Gray, 2005) and elsewhere.

\subsection{Combined approaches}

Because the range offsets from speckle tracking and the phase from interferograms both provide measurements of $\Delta$, either can be combined with azimuth offsets to produce a horizontal velocity estimate. For example, interferometric phase can be used in place of the range offsets and combined with the speckle-tracked azimuth offsets to produce a more accurate estimate in the range direction. Over large regions with a range of flow speeds, a variety of data may be available, including phase in two or more directions, phase in one direction and azimuth offsets in the other, or both range and phase offsets. Consequently, over wide areas best results are often obtained by merging all the available data, with each type of estimate weighted by its level of uncertainty (Joughin, 2002). Because both methods rely on interferometric coherence and can be merged as just described, we use the term InSAR throughout this paper to mean any estimate derived from a combination of phaseand/or speckle-tracking methods. These methods represent a steady evolution from early interferograms covering parts of an ice stream in the 1990s (Fig. 1) to the current ability to map velocity over ice-sheet-sized areas (Fig. 3). 


\subsection{Current and past sensors}

Several civilian SARs have been launched that collect data suitable for interferometric (phase- or speckle-tracking) measurements over ice. The first of these was the ERS-1 satellite, launched by ESA in 1991, which was followed by ERS-2 and Envisat, all of which operated at C-band $(\lambda=5.65 \mathrm{~cm})$. An advantage for many of the early demonstrations of InSAR over ice sheets was that, from 1991 to 1994, there were three periods when ERS-1 was placed in a 3 day repeat orbit, which worked well for measuring ice motion (e.g. Goldstein and others, 1993; Joughin and others, 1995; Rignot and others, 1995). In 1995 ESA launched the nearly identical ERS-2 and placed it in the same orbit as ERS1 , except that one satellite followed the other 24 hours later. The resulting 'tandem' 1 day interferograms were well suited to measuring ice-sheet and glacier motion, particularly in areas of fast flow and high strain rates (e.g. Mattar and others, 1998), since decorrelation and phase aliasing were relatively small over this short interval. The first tandem phase ended in June 1996 and was resumed for several periods through 2000. These two satellites also collected a substantial volume of 35 day repeat data, the best use of which is for speckle tracking in low-accumulation areas where the temporal decorrelation tends to be moderate. The follow-on Envisat SAR was launched in 2002 and has collected a substantial volume of data for ice-sheet mapping in its 35 day orbit (e.g. Luckman and others, 2006). Tandem operations between Envisat and ERS-2 have been conducted, but the data are more difficult to use because the radars operate at slightly different frequencies.

The Canadian Space Agency (CSA) developed the C-band RADARSAT-1 SAR, which was launched by NASA in 1995. Twelve years later, CSA followed the success of RADARSAT-1 with the 2007 launch of RADARSAT-2. Both of these satellite missions have commercial objectives, which limits data availability. Over Greenland and Antarctica, however, CSA in partnership with NASA has made a large volume of RADARSAT- 1 data available for scientific research. Many of these data were collected during the Antarctic Mapping Mission (AMM) in 1997, when the spacecraft was manoeuvred to be south-facing for full continental coverage, collecting data from 26 September through 20 October (Jezek, 1999), and the Modified Antarctica Mapping Mission (MAMM) in 2000, when three 24 day repeat passes of data were collected in the normal north-looking orientation (Jezek and others, 2003).

The Japan Aerospace Exploration Agency (JAXA) launched J-ERS-1 SAR (44 day repeat) in 1992 and the ALOS Phased Array-type L-band SAR (PALSAR) (46 day repeat) in 2006 , both operating at L-band $(\lambda=23.6 \mathrm{~cm})$. There has only been limited application of the earlier J-ERS-1 satellite to ice sheets (e.g. Cheng and Xu, 2006), but large volumes of PALSAR data have been collected in Antarctica (e.g. Rignot, 2008). The long repeat periods ( 44 and 46 days) of these two satellites are partially mitigated by the longer L-band wavelength, which means they provide performance, in terms of temporal decorrelation, that is roughly equivalent to 11 days at C-band.

Near the magnetic poles, including large portions of the ice sheets, the ionosphere causes phase variability and streak-like errors in the azimuth speckle-tracked offsets (Gray and others, 2000; Rignot, 2000). Because the ionospheric errors are wavelength-dependent, they tend to be worse with the $\mathrm{L}$-band radars relative to $\mathrm{C}$ - and X-band radars.

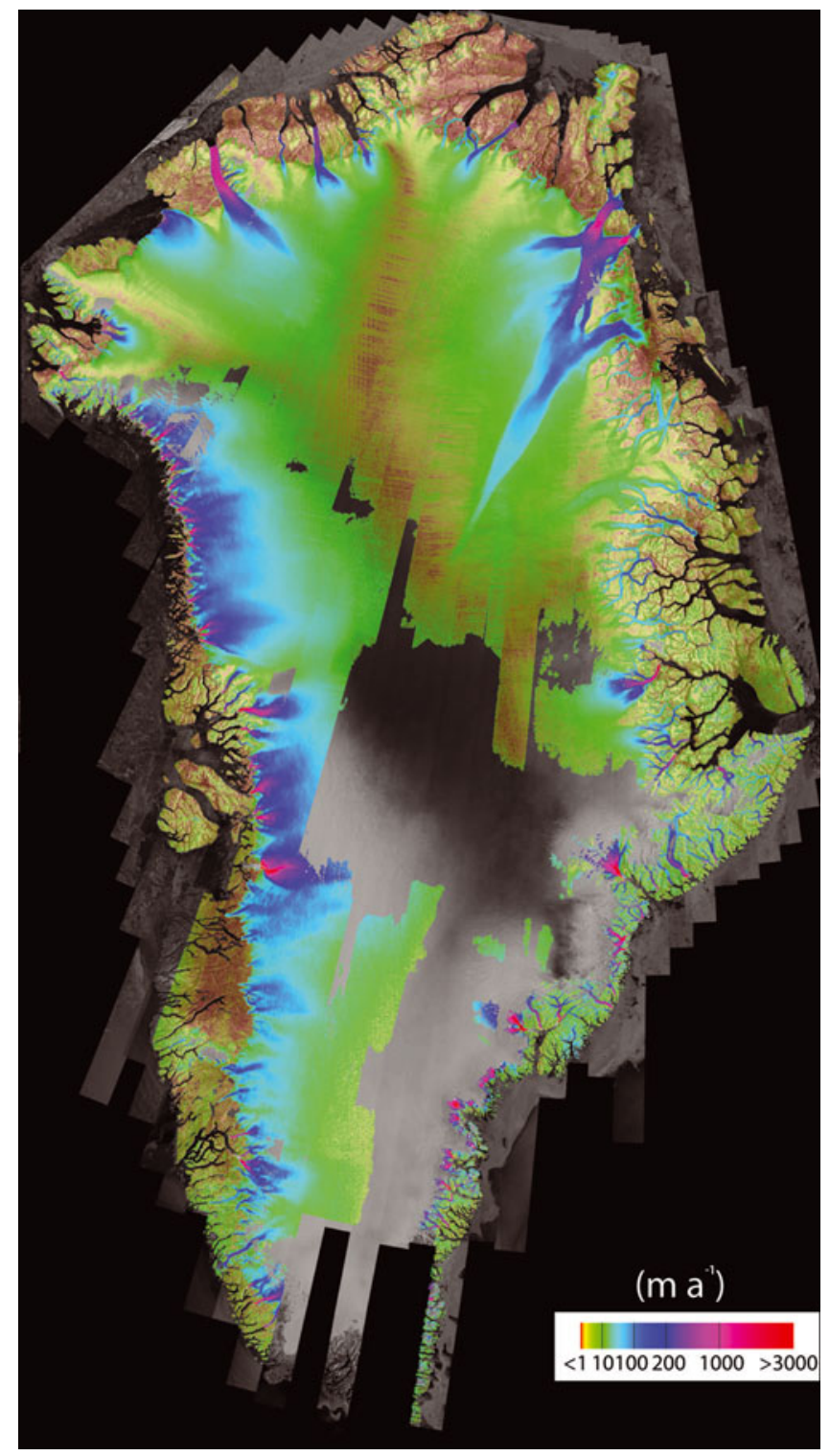

Fig. 3. Greenland flow speed for the 2005/06 winter derived from a combination of interferometric phase and speckle tracking (adapted from Joughin and others, 2010a).

The German Aerospace Research Center (DLR) launched the X-band $(\lambda=3.1 \mathrm{~cm})$ TerraSAR-X satellite in 2007, the same year that the Italian Space Agency (ASI) began launching a four-satellite constellation, COSMO-SkyMed (COnstellation of small Satellites for the Mediterranean basin Observation), of X-band SARs. The 11 day repeat period of TerraSAR-X is equivalent to $\sim 20$ days at C-band, making it best suited to speckle tracking for glacier motion. The COSMO-SkyMed constellation will allow for more rapid repeats. The much finer resolution of these two instruments, relative to their longer-wavelength C- and Lband counterparts, makes them well suited to mapping fastmoving narrow outlet glaciers such as those in the Antarctic Peninsula (Rott and others, 2010) and alpine glaciers.

\section{InSAR CONTRIBUTIONS TO GLACIOLOGY}

As detailed in numerous studies cited below, one of the greatest contributions of InSAR to glaciology is its ability to map ice flow over large areas and entire ice sheets. As 


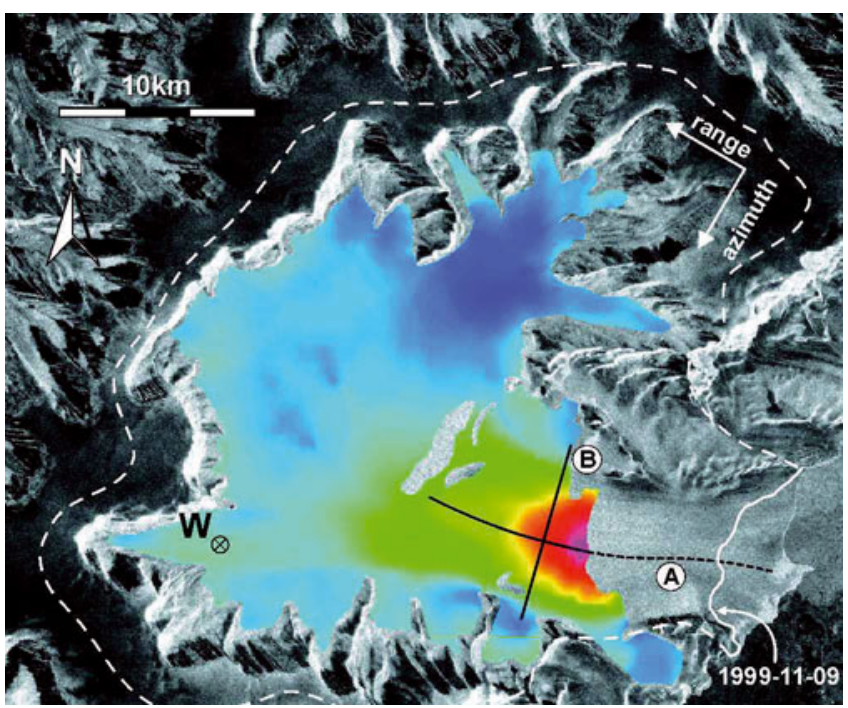

Fig. 4. Change in flow speed (color) on Drygalski Glacier from November 1995 to November 1999 derived from ERS tandem data. The speed-up occurred during a period when the grounded ice retreated by $\sim 5 \mathrm{~km}$, following the loss of the Larsen $A$ ice shelf in early 1995 (Rott and others, 2002).

opposed to pre-InSAR times when a complex feature such as an ice stream might be characterized by a sparse set of points, we can now visualize and study outlet glaciers and ice streams as complete features along with their corresponding tributary systems. With existing datasets, flow velocity has now been mapped over the majority of the area comprising the Greenland and Antarctic ice sheets (references below and unpublished ongoing work by many groups) at least once. While less comprehensive, flow velocity for many ice caps and mountain glaciers has also been mapped using InSAR. In addition, numerous mountain glacier studies have used the SRTM elevation data as described below. The following subsections detail how velocity and topographic maps from InSAR have contributed to major advances in our understanding of many aspects of glacier and ice-sheet flow.

\subsection{Flow variability}

Simple models suggest that the response times of ice sheets to shifts in surface mass balance are measured in millennia (Paterson, 1994), which is similar to the response times predicted by most more sophisticated whole ice-sheet models (e.g. Huybrechts and de Wolde, 1999). Such results, in conjunction with a dearth of observations, led to the conventional wisdom that present ice-sheet flow should not change rapidly (i.e. at decadal to sub-decadal timescales), although theoretical concepts such as ice-shelf buttressing suggested that rapid change could occur (Mercer, 1978; Paterson, 1994). Observations of flow variability, largely from InSAR, have overturned this notion of sluggishly changing ice sheets and have clearly demonstrated that large changes in flow can and do occur abruptly.

In Antarctica, InSAR supplemented by optical featuretracking data revealed that Pine Island Glacier (PIG) has sped up over a period of more than three decades (Rignot and others, 2002; Joughin and others, 2003; Rignot, 2006, 2008). Several neighbouring glaciers along the Amundsen Coast have also accelerated over the same period (Rignot and others, 2002; Rabus and others, 2003; Rignot, 2008). Along the Antarctica Peninsula, ERS data revealed that Drygalski Glacier sped up by a factor of 3 near its retreating terminus, following the loss of the Larsen A ice shelf as illustrated in Figure 4 (Rott and others, 2002). Similarly, InSAR and Landsat observations have revealed substantial (up to eight-fold) glacier speed-up following the break-up of the adjacent Larsen B ice shelf (Rignot and others, 2004a; Scambos and others, 2004) and the Wordie Ice Shelf on the west side of the Peninsula (Rignot and others, 2005), providing direct observational evidence of the theoretical concept of buttressing set forth more than two decades earlier (Mercer, 1978; Paterson, 1994 and references therein).

Along the heavily studied Siple Coast, shallow icepenetrating radar revealed the shutdown of Kamb Ice Stream (former Ice Stream C) around AD 1850 (Retzlaff and Bentley, 1993), but it was RADARSAT InSAR observations that revealed the full extent of the still-active regions flowing behind the stagnant region (Fig. 5) (Joughin and others, 1999b; Price and others, 2001). In the adjacent catchment of the still active Whillans Ice Stream, InSAR-derived velocity maps combined with field measurements of velocity revealed a three-decade-long steady deceleration, which at the present rate of slowdown would lead to a complete stagnation in $~ 70$ years (Joughin and others, 2002, 2005; Stearns and others, 2005).

In Greenland, InSAR- and Landsat-derived velocities revealed that Jakobshavn Isbræ, the glacier with the largest discharge from the ice sheet's western margin, nearly doubled its speed between 1997 and 2003 (Joughin and others, 2004b), a period that saw substantial wastage in Jakobshavn Isbræ and strong thinning of $\sim 15 \mathrm{~m} \mathrm{a}^{-1}$ (Krabill and others, 2004). Analysis of the changes on Jakobshavn Isbræ indicates a direct coupling between outlet glacier flow rates and resistive stress associated with the seasonal variation in the terminus extent (Joughin and others, 2008a). Since 2003, the glacier has maintained its high speed of $\sim 14 \mathrm{~km} \mathrm{a}^{-1}$ (Luckman and Murray, 2005; Joughin and others, 2008a). Over roughly the same period (200205), the two largest glaciers on Greenland's east coast, Kangerdlugssuaq Gletscher and Helheimgletscher, also sped up dramatically as their respective termini retreated (Howat and others, 2005; Luckman and others, 2006), with earlier observations from the 1990s on Kangerdlugssuaq indicating some precursor thinning and variation in speed (Thomas and others, 2000). During this period, many of the glaciers in the southeast and northwest also sped up substantially (Rignot and others, 2004b, 2008a; Rignot and Kanagaratnam, 2006; Howat and others, 2008; Joughin and others, 2010a).

For many decades, numerous glaciological studies have focused on surge behaviour on both temperate and polar glaciers (Paterson, 1994). While a surge in North Greenland in the 1980s on Storstrømmen occurred before spaceborne SAR observations were available, the upstream flow into the now stagnant terminus following the surge has been well mapped with InSAR (Mohr and others, 1998; Reeh and others, 2003). In East Greenland, a major surge from 1992 to 1995 on Sortebræ was observed with ERS data (Murray and others, 2002; Pritchard and others, 2005). In addition to changes in speed, Pritchard and others (2003) used InSARderived DEMs to measure a $24 \mathrm{~km}^{3}$ volume change in Sortebræ's upper catchment over the 28-32 month long surge event, which likely was caused by a shift from a channelized to distributed drainage (Pritchard and others, 2005). Several other instances of surge behaviour have been 


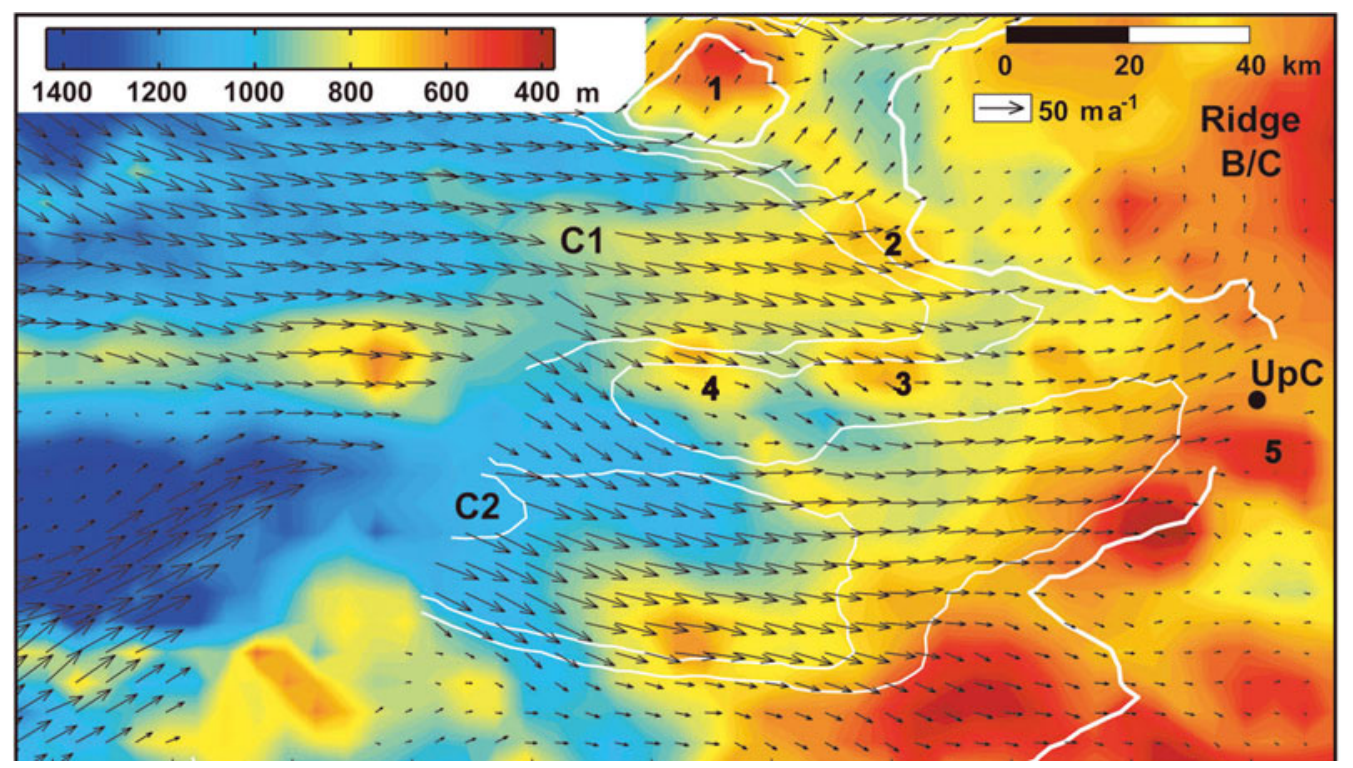

Fig. 5. Velocity (black vectors) derived from RADARSAT data at the transition from active to stagnant flow on Kamb Ice Stream, superimposed on the elevation of the bed below sea level (color). Flow speed is also shown with $15 \mathrm{~m} \mathrm{a}^{-1}$ white contours (Price and others, 2001).

noted in comprehensive mappings of Greenland (Rignot and others, 2001a; Rignot and Kanagaratnam, 2006; Joughin and others, 2010a).

Away from the ice sheets, numerous other studies have used interferometric methods to observe surge behaviour. In Spitsbergen, ERS data have proven useful for monitoring Monacobreen during a surge in the mid-1990s (Luckman and others, 2002). Over a 6 year period (1991-97) on Svalbard's 12 km long Fridtjovbreen, InSAR data captured a slow, steady rise in velocity, leading to a much more abrupt acceleration to a peak speed of $2.5 \mathrm{~m} \mathrm{~d}^{-1}$ in 1996, followed by deceleration in 1997 (Murray and others, 2003). In Iceland, InSAR mapping of several glaciers draining the Langjökull ice cap detected increased speeds in 1994, which may be the result of an otherwise undetected surge on Sudurjökull (Palmer and others, 2009). Surges have also been observed on Dyngjujökull and Sylgjujökull from ERS data collected over the Vatnajökull ice cap, Iceland (Fischer and others, 2003). In Alaska, Fatland and Lingle (1998) used InSAR to detect speed-up by a factor of 2.7 on the West Bagley Icefield, which appears to be an upstream response to the 1993-95 surge of Bering Glacier.

\subsection{Ice-sheet processes}

The ability to measure surface displacement using InSAR has provided many new observations that are fundamental to improving our understanding of the processes that control the fast flow of ice sheets. These applications include everything from basic velocity maps used for making qualitative inferences to model-based inversions used for quantitatively inferring basal properties. The knowledge of the physics of ice flow that can be gained using InSAR combined with other data is of critical importance for removing the large uncertainties in present assessments of sea-level rise over the next several centuries (Solomon and others, 2007).

While it has long been known that mountain glaciers exhibit a dynamic response to seasonal variation in surface melt that lubricates the bed (Paterson, 1994), InSAR measurement of rapid speed-up during an apparent lake drainage gave a strong indication that ice sheets could respond similarly (Joughin and others, 1996a). Another example of this sensitivity to melt was found at Swiss Camp near the equilibrium line in central-west Greenland, where GPS recorded seasonally varying flow in response to summer melt over several years, with mid-summer speed-ups of as much as $28 \%$ (Zwally and others, 2002). Subsequently, time series of velocity measured with InSAR revealed much larger summer speed-ups (50-100\%) in response to summer melt on the slower-moving $\left(\sim 100 \mathrm{~m} \mathrm{a}^{-1}\right)$ areas in the ablation zone along an extended section of the Greenland ice sheet's western margin (Joughin and others, 2008b; Shepherd and others, 2009). These InSAR data, however, also demonstrated that while fast $\left(>1000 \mathrm{~m} \mathrm{a}^{-1}\right)$ outlet glaciers and slowerflowing $\left(\sim 100 \mathrm{~m} \mathrm{a}^{-1}\right)$ ice both speed up by similar amounts $\left(\sim 50 \mathrm{~m} \mathrm{a}^{-1}\right)$, in relative terms, the change is too small to have a substantive effect on the net ice discharge from the ice sheet. In addition to measuring velocity response to seasonal melt, InSAR-derived surface topography and slope have also proven useful for studying the subglacial hydrologic system that channels this melt that reaches the bed (Ahlstrøm and others, 2005).

Field observations have revealed substantial uplift associated with the movement and storage of subglacial water (Paterson, 1994). The first use of InSAR to detect surface displacement associated with subglacial water flow appears to have been on the Bagley Icefield, where patterns of concentric fringes, or 'bull's-eyes', visible in ERS interferograms indicated what appears to be the downstream migration of pockets of subglacial water (Fig. 6) (Fatland and Lingle, 2002). Similarly, in Antarctica, RADARSAT data revealed what appears to be the surface uplift and subsidence associated with the filling and draining of a connected system of subglacial lakes, providing the first indication of active subglacial lakes associated with ice streams and the first demonstration of true 3-D displacement measurements made with speckle tracking applied to ascending and descending orbits (Gray and others, 2005). 


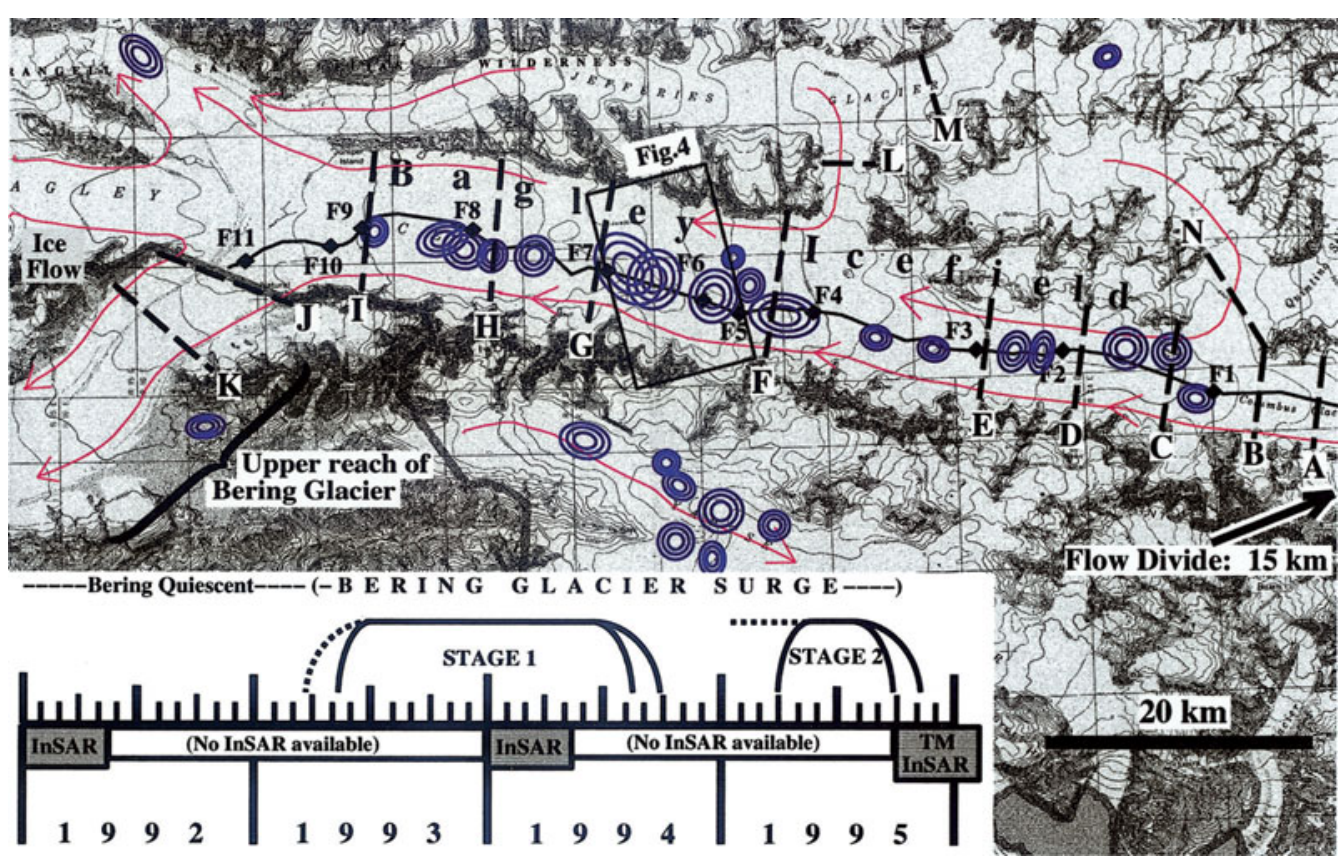

Fig. 6. Locations (blue) of interferometrically determined transient patterns of vertical uplift, or 'bull's-eyes', believed to be associated with the migration of subglacial water pockets, plotted over a map of the Bagley Icefield, Alaska (Fatland and Lingle, 2002).

Beneath the slow-moving ice sheet in East Antarctica, a combination of radar altimetry and InSAR detected the movement of $1.8 \mathrm{~km}^{3}$ of water from a subglacial lake to two other lakes $>290 \mathrm{~km}$ away (Wingham and others, 2006). In another study of subglacial lakes in East Antarctica, Bell and others (2007) observed that the lake locations determined using other methods correspond well with the upstream end of Recovery Ice Stream as indicated by RADARSAT-derived velocity maps, suggesting the subglacial lakes may play a role in the initiation of fast flow for that ice stream. In a region of much slower flow, Kwok and others (2000) used ERS data to measure ice flow around Vostok Subglacial Lake to infer a minimum freezing rate of $40 \mathrm{~mm} \mathrm{a}^{-1}$.

In several studies, comparison of velocity maps with other data has been important for understanding ice-sheet processes. For example, Fahnestock and others (2001) analysed the patterns of flow in the Northeast Greenland Ice Stream' using an ERS-derived velocity map in conjunction with several other datasets. Several studies have analysed the differences between estimated balance velocities and velocities measured with InSAR, enabling identification of areas of dynamic imbalance (Bamber and others, 2000a,b,c). In East Antarctica, comparison of subglacial topography with InSAR-derived surface velocity was used to infer the presence of a sedimentary basin beneath Slessor Ice Stream (Bamber and others, 2006). Along the Siple Coast, InSAR velocities have proven useful for inferring past changes in flow direction (Price and others, 2001; Siegert and others, 2003). In the Amundsen Sea embayment, comparison of velocity and altimetry measurements reveals a close correspondence between thinning and fast flow, indicating that the ice loss is a dynamic response (Shepherd and others, 2002). Interferometric velocity maps also have proved useful for studying and interpreting conditions around drill site locations (Legrésy and others, 2000; Siegert and others, 2004).

Traditional force-balance methods use velocity data to estimate the various stresses contributing to ice flow
(Whillans, 1987). On the Siple Coast, force-balance analysis using RADARSAT-derived velocities has been used to investigate the relative role of basal and lateral drag (Joughin and others, 2002; Stearns and others, 2005). Using forcebalance methods applied to ERS data from East Antarctica, Pattyn and Derauw (2002) determined that lateral drag supports up to $\sim 15 \%$ of the driving stress near the grounding line of Shirase Glacier.

Even though gridded velocity data were not yet available, MacAyeal (1993) presciently developed methods from optimal control theory for inverting an ice-stream flow model for basal shear stress, using the types of densely gridded velocity maps that InSAR methods would later make routine. These methods were first applied to datasets from Landsat feature tracking (MacAyeal and others, 1995) and have since been applied to several ice streams in Antarctica (Joughin and others, 2004a, 2006, 2009; Morlighem and others, 2010). Collectively, these studies revealed that the Siple Coast ice streams have extensive areas of weak till, while other West Antarctic ice streams have much larger intra-stream areas of strong bed that support larger driving stresses. In Greenland, similar control-method inversions revealed a large weak-bedded area near where the 'Northeast Greenland Ice Stream' branches to feed Zachariæ Isstrøm and Nioghalvfjerdsfjorden (Joughin and others, 2001). Other methods have also been developed for using gridded velocities to invert for basal properties (Thorsteinsson and others, 2003).

Velocity fields derived from InSAR have also been used in many forward-modelling studies. For instance, on PIG, several authors have used InSAR data to tune models to examine the response to changes in geometry and grounding-line position (Schmeltz and others, 2002a; Payne and others, 2004; Thomas and others, 2004; Joughin and others, 2010b). Interferometrically determined velocities have also been used to determine horizontal advection in studies that modelled englacial temperature and basal melt rates (Vogel and others, 2003; Joughin and others, 2004c, 2009). In 
model-based studies of the stagnation of Kamb Ice Stream and of the ongoing slowdown of Whillans Ice Stream (Bougamont and others, 2003a,b), RADARSAT-derived velocities have provided an important constraint. Other studies have used forward models in conjunction with InSAR velocity measurements to investigate ice flow in the tributaries feeding the Siple Coast ice streams (Hulbe and others, 2000, 2003; Wang and others, 2003). In Greenland, Nick and others (2009) used InSAR and other velocities in a forward-modelling based study of the response of Helheimgletscher to terminus forcing and the resulting upslope migration of acceleration and thinning.

\subsection{Ice-shelf processes}

When an ice sheet thins to flotation at its grounded margin, it often extends seaward to form a floating ice shelf. Much of the Antarctic coastline is bordered by such floating ice shelves, and, because the surface temperatures are rarely above freezing, most mass loss from melting occurs at the ice-ocean interface beneath these shelves (e.g. Jacobs and others, 1992). Ice shelves also restrain the flow from the interior, so the abrupt loss of an ice shelf reduces buttressing of the grounded ice, speeding flow and increasing ice discharge to the ocean (Paterson, 1994). The position of the grounding line, the transition from grounded to floating ice, also represents an important control on ice discharge.

One of the first applications of InSAR to ice shelves was observation of the vertical motion associated with tidal flexing to reveal grounding line position (Goldstein and others, 1993). Best results are obtained when two interferograms are differenced to cancel the uniform horizontal motion, yielding a band of fringes in the region of flexure associated with the different tidal displacements captured by each interferogram (Rignot, 1996). This method was used to detect a $5 \mathrm{~km}$ retreat of the PIG grounding line in the 1990s and more minor retreat on Thwaites Glacier (Rignot, 1998b, 2001) and has also been applied to map grounding lines in many locations around Greenland (Rignot, 1998c; Rignot and others, 2001a) and Antarctica (Rignot, 1996, 1998a, 2002; Rabus and Lang, 2002; Schmeltz and others, 2002b; Fricker and others, 2009). Similar interferometric techniques have also revealed ephemeral grounding points (Fig. 7), where the ice shelf is grounded only during the low parts of the tidal cycle (Schmeltz and others, 2001). In cases where the temporal baseline is too long, the phase fringes alias so that the grounding line cannot be detected. Less accurate estimates can be derived, however, if the aliased fringes produce an apparent loss of coherence (coherence is maintained but the estimate is biased low by the phase gradient in the flexure zone), which in turn produces an identifiable grounding line signature (Gray and others, 2002). Alternatively, in lieu of phase, speckle-tracked range offsets can be used if they are accurate enough to determine tidal displacement (Joughin and others, 2010a). The vertical motion associated with tidal displacement has also been studied at ice-shelf locations well away from the grounding line using InSAR (Rignot and others, 2000b).

Prior to the availability of InSAR measurements, horizontal flux divergence had been used to infer basal melt rates (Jenkins and Doake, 1991). The velocity grids provided by InSAR are ideal for such estimates, and have been used in many studies for determining basal melt rates. One of the first applications of this technique was to Petermann Gletscher, North Greenland (Rignot, 1996; Rignot and

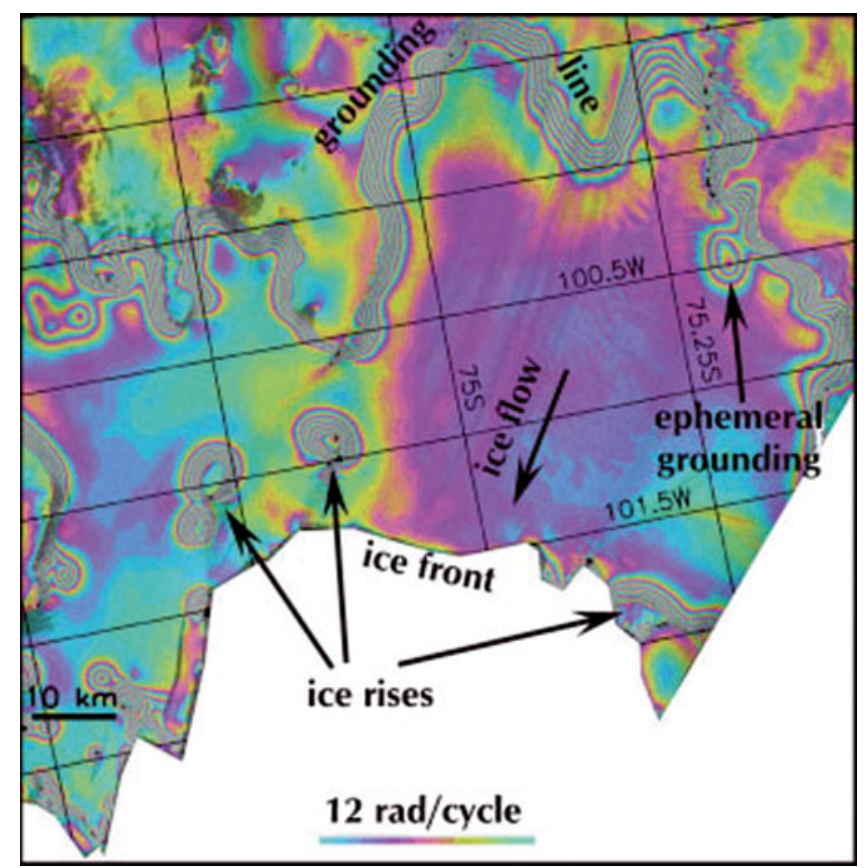

Fig. 7. Double-differenced interferogram of the ice shelf in the Pine Island embayment showing tidal displacement. The bands of fringe reveal flexure at the main grounding line, several ice rises and an ephemerally grounded spot (Schmeltz and others, 2001).

others, 2001a; Rignot and Steffen, 2008), where melt rates far larger than earlier estimates were derived. In Antarctica, Rignot and Jacobs (2002) applied this technique to several ice shelves to estimate a sensitivity of melt to temperature, indicating that each increase in ocean temperature by $1^{\circ} \mathrm{C}$ corresponds to a $10 \mathrm{~m} \mathrm{a}^{-1}$ increase in the basal melt rate. In another case, flux-divergence based estimates for the Filchner-Ronne Ice Shelf revealed that much of the neargrounding-line melt refreezes beneath the middle of the shelf so that tidal-current driven melt near the shelf front produces the greatest net melt (Joughin and Padman, 2003). The freeze-on rates from this study were later used to estimate the marine ice thickness, producing good agreement with independent results derived from airborne radioecho sounding (Joughin and Vaughan, 2004). Beneath the Amery Ice Shelf, similar methods revealed patterns of melting and freezing using a RADARSAT-derived velocity map (Wen and others, 2007).

Calving and rifting are both processes that are important to ice-shelf stability. Alley and others (2008) used InSAR velocity data from several ice shelves to derive a relation suggesting the calving rate is largely determined by the ice shelf's along-flow spreading rate. Other studies have made extensive use of ice-shelf velocity fields for studying the processes of rift propagation on the Filchner-Ronne (Larour and others, 2004a, b; Hulbe and others, 2010), Ross (Joughin and MacAyeal, 2005) and Brunt/Stancomb-Wills Ice Shelves (Humbert and others, 2009; Khazendar and others, 2009).

In addition to fracture-related processes, InSAR data have been used extensively for investigating ice-shelf rheology. For example, using control-method inversions similar to those used to determine basal shear stress for grounded ice, investigators have inverted for rheological parameters of the Filchner-Ronne (Larour and others, 2005) and Larsen B ice shelves (Vieli and others, 2006, 2007; Khazendar and others, 2007). Other studies have relied on a forward-modeling 
approach to examine the sensitivity of shelf flow to ice rheology (Hulbe and others, 1998, 2005). In addition to viscous properties, several studies have used InSAR velocity fields to investigate the elastic properties of ice shelves related to tidal flexing (Rabus and Lang, 2002; Schmeltz and others, 2002b; Legrésy and others, 2004; Sykes and others, 2009). Young and Hyland (2002) analysed InSAR-determined strain rates on the Amery Ice Shelf and found longitudinal bands of enhanced shear that likely indicate the development of a strong fabric favouring shear.

\subsection{Ice-sheet mass balance}

Altimetry (e.g. Krabill and others, 2004; Zwally and others, 2005), satellite gravity (e.g. Luthcke and others, 2006; Velicogna and Wahr, 2006), and flux-gate methods (see citations below) have all been used to estimate ice-sheet mass balance. With the flux-gate method, velocity and ice thickness near the grounding line are used to estimate ice discharge, which is differenced with an estimate of the net upstream surface mass balance to determine the total net mass balance. Prior to InSAR, flux-gate methods were applied to sparse field data (e.g. Shabtaie and Bentley, 1987), but they are now widely used with the much better coverage InSAR provides. In most cases, the velocity data contribute the smallest uncertainty to these estimates. The errors associated with the thickness measurements can range from relatively small when acquired with radar echo sounding to potentially much larger when thickness is inferred from radar altimetry data on floating ice (e.g. Rignot and Thomas, 2002). In most cases, uncertainty is dominated by the knowledge of the accumulation rates, which are either gridded from sparse measurements or derived from regional climate models (Rignot and others, 2008b). In cases where the accumulation and thickness are poorly known, different flux-gate studies can produce substantially differing results (e.g. Rignot and others, 2004a; Rott and others, 2010).

Early flux-gate estimates focused on the north and east coasts of Greenland, where ERS data were well suited to mapping ice flow (Rignot and others, 1997; Joughin and others, 1999a; Rignot and others, 2000a, 2001a, 2004b). When CSA targeted Antarctica during MAMM in 2000, it also collected complementary coverage in Greenland. Combined with earlier ERS data, RADARSAT data allowed a nearly complete flux-gate based assessment of Greenland's mass balance at multiple times (Rignot and Kanagaratnam, 2006). This assessment showed an excess ice discharge from Greenland of 51 Gtons a $^{-1}\left(0.14 \mathrm{~mm} \mathrm{a}^{-1}\right.$ sea-level equivalent (SLE)) in 1996, increasing to 152 Gtons $^{-1}\left(0.42 \mathrm{~mm} \mathrm{a}^{-1} \mathrm{SLE}\right)$ in 2005, which then decreased slightly in 2006 and 2007 (Rignot and others, 2008a). This increase in discharge was accompanied by large thinning at the termini of the glaciers that sped up, highlighting the need for thickness-change information in flux-gate estimates to account for temporal variations in outlet-glacier cross section (Howat and others, 2007).

Long-standing concern over the stability of the West Antarctic ice sheet (e.g. Mercer, 1978) was increased by flux-gate estimates showing a $25 \%$ negative mass imbalance for the Ross ice streams (Shabtaie and Bentley, 1987). The RADARSAT AMM rotated the instrument from its usual northward-looking configuration to image southwards, providing the first SAR coverage south of $\sim 80^{\circ} \mathrm{S}$. An InSAR flux-gate analysis based on these data showed that, contrary to the earlier negative estimate (Shabtaie and Bentley, 1987), the Ross ice streams have a $25 \%$ positive imbalance (Joughin and Tulaczyk, 2002), largely due to the stagnation of Kamb Ice Stream and the ongoing deceleration of Whillans Ice Stream.

Concern shifted to the Amundsen Coast when flux-gate estimates revealed losses of 65 Gtons a $^{-1}\left(0.18 \mathrm{~mm} \mathrm{a}^{-1} \mathrm{SLE}\right)$ (Rignot and Thomas, 2002). Subsequent estimates (Fig. 8) with improved accumulation estimates indicate an imbalance for all of West Antarctica of $106 \pm 60 \mathrm{Gtons} \mathrm{a}^{-1}$ $\left(0.29 \pm 0.17 \mathrm{mma}^{-1} \mathrm{SLE}\right)$ in 2000 , increasing to $132 \pm$ 60 Gtons $^{-1}$ in $2006\left(0.37 \pm 0.17 \mathrm{mma}^{-1} \mathrm{SLE}\right)$ with the speed-ups on PIG and other Amundsen Coast glaciers (Rignot and others, 2008b). In contrast, parts of East Antarctica show a net thickening (Rignot and Thomas, 2002), in particular those feeding the Filchner-Ronne Ice Shelf (Joughin and Bamber, 2005). With almost no net loss in East Antarctica and losses of $60 \pm 46$ Gtons $^{-1}\left(0.17 \pm 0.13 \mathrm{~mm} \mathrm{a}^{-1} \mathrm{SLE}\right)$ in the Antarctica Peninsula, the total flux-gate mass loss estimate for Antarctica in 2006 is $196 \pm 92$ Gtons $\left(0.54 \pm 0.26 \mathrm{~mm} \mathrm{a}^{-1}\right.$ SLE) (Rignot and others, 2008b).

As noted earlier, the flux-gate method is one of three major techniques for estimating mass balance, the others being gravity- and altimetry-based. In some cases, there is good agreement between flux-based estimates and these other geodetic techniques, while in others there is substantial disagreement. For example, flux-gate methods suggest strong thinning along the Bellingshausen Coast (Ferrigno-Abbot Ice Shelves; see second largest red dot in Fig. 8), which radar and laser altimetry do not detect (Rignot and others, 2008b; Pritchard and others, 2009). Such differences provide valuable information, however, revealing much about the factors that limit the accuracy of each technique. In particular, the flux-based method and associated velocities reveal change on the most rapidly evolving aspects of ice-sheet mass balance: discharge at outlet glaciers and ice streams. As a result, the contributions made by InSAR and flux-gate methods toward understanding mass balance, its rate of change and the role of ice dynamics in those changes are indispensable.

\subsection{Mountain glaciers}

Relative to ice sheets, the smaller sizes, steeper slopes and often far higher accumulation and ablation rates of mountain glaciers provide a more challenging environment in which to apply interferometric methods. Despite these limitations, several studies have succeeded in using InSAR for studying mountain glaciers. Some of these difficulties may also be mitigated as finer-resolution data become available (Short and Gray, 2004). In addition to glacier flow, many studies have taken advantage of the high-resolution topography data from the SRTM mission, which covered many of the world's glaciated regions outside Greenland and Antarctica (Farr and others, 2007).

On Seward Glacier, Alaska, interferometric data were used to study the interaction of glacier flow with the regional tectonics (Ford and others, 2003). On Black Rapids Glacier, Alaska, ERS data revealed a winter to summer along-flow transition from compression to extension (Rabus and Fatland, 2000) and a motion anomaly that may have been caused by a failed surge (Fatland and others, 2003). The surge of Bering Glacier from 1993 to 1995 coincided with acquisition of some of the earlier ERS-1 SAR data over Alaska (Fatland, 1997; Fatland and Lingle, 1998, 2002). 


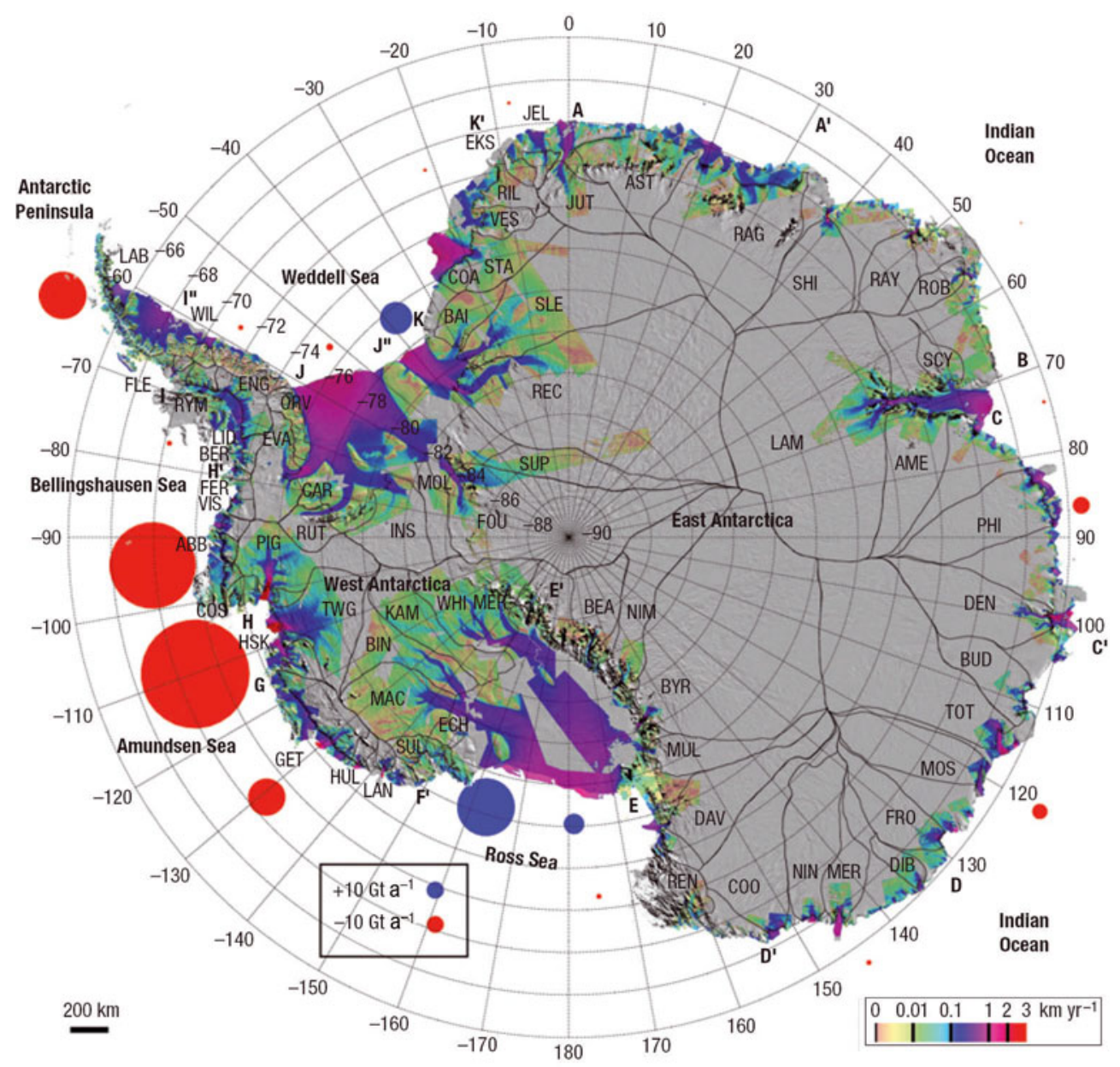

Fig. 8. Mass-balance estimates (circles) for the major drainages of the Antarctic ice sheet along with the associated InSAR velocity estimates (color) (Rignot and others, 2008b). Reprinted by permission from Macmillan Publishers Ltd. Nature Geoscience 1(2), 106-110, (C) 2008.

On Devon Ice Cap, Canadian Arctic, Burgess and others (2005) used a combination of ERS and RADARSAT data to study sliding and outlet-glacier calving (Fig. 9). Elsewhere in the Canadian Arctic, Short and Gray (2005) performed a survey of several glaciers over a 4 year period on Axel Heiberg and Ellesmere Islands to find a wide range of flow speeds and evidence of apparent surge behaviour. In the Himalaya, Luckman and others (2007) derived velocity fields showing that Khumbu glacier is nearly stagnant, while Kangshung glacier flows comparatively rapidly at $36 \mathrm{ma}^{-1}$. In Iceland, ERS-1/-2 data revealed that water released during the early stages of two jökulhlaups reduced coupling to the bed and increased sliding, with subsequent deceleration as tunnels developed (Magnússon and others, 2007, 2010). In the Southern Hemisphere, Glaciar Moreno has been mapped extensively with data from the Shuttle Imaging Radar/X-SAR (Rott and others, 1998; Michel and Rignot, 1999) and COSMOS-SkyMed (Ciappa and others, 2010).

While InSAR is used primarily for measuring motion in glacier studies, interferometrically derived DEMs combined with other DEM and elevation data can be used to determine volume change. The surface lowering of several Alaskan glaciers has been measured using a combination of the SRTM DEM, airborne InSAR DEMs and other elevation data (Muskett and others, 2008a,b, 2009). Similar methods have been applied to derive a time series of thinning on several glaciers in the ice fields of British Columbia, Canada (VanLooy and Forster, 2008). In Patagonia, Rignot and others (2003) used the SRTM DEM, in conjunction with historic elevation maps, to find a pattern of widespread thinning across 63 glaciers, producing a net loss of 38 Gtons $^{-1}$ (0.105 $\left.\mathrm{mm} \mathrm{a}^{-1} \mathrm{SLE}\right)$.

\subsection{Glacial geology}

The results described above are based on interferometric measurements of contemporary glaciers and ice sheets. The seamless DEM produced by SRTM, however, reveals much about the glacial geology of past ice sheets. For example, Fisher and others (2009) mapped moraines and flood channels to study meltwater routing and retreat of the margin of the Laurentide ice sheet in the Fort McMurray region of Alberta and Saskatchewan (Fig. 10). Similar methods applied to SRTM maps were used to study retreat of the Laurentide ice sheet near Thunder Bay (Lowell and others, 2009). In another application, Shaw and others (2010) produced a flowline map for regions of Canada covered by the Laurentide and Cordilleran ice sheets from glacial features such as drumlins and flow-parallel landforms visible in the SRTM DEM and other satellite imagery. The SRTM DEM has also been used to study changes in the flow of Laurentide terrestrial ice streams in the vicinity of the western Canadian prairies (O'Cofaigh and others, 2010). In South America, SRTM data have proven useful for studying the glacial geomorphology and the Pleistocene history of the Patagonian Icefields (Glasser and Jansson, 2005; Glasser and others, 2008). 


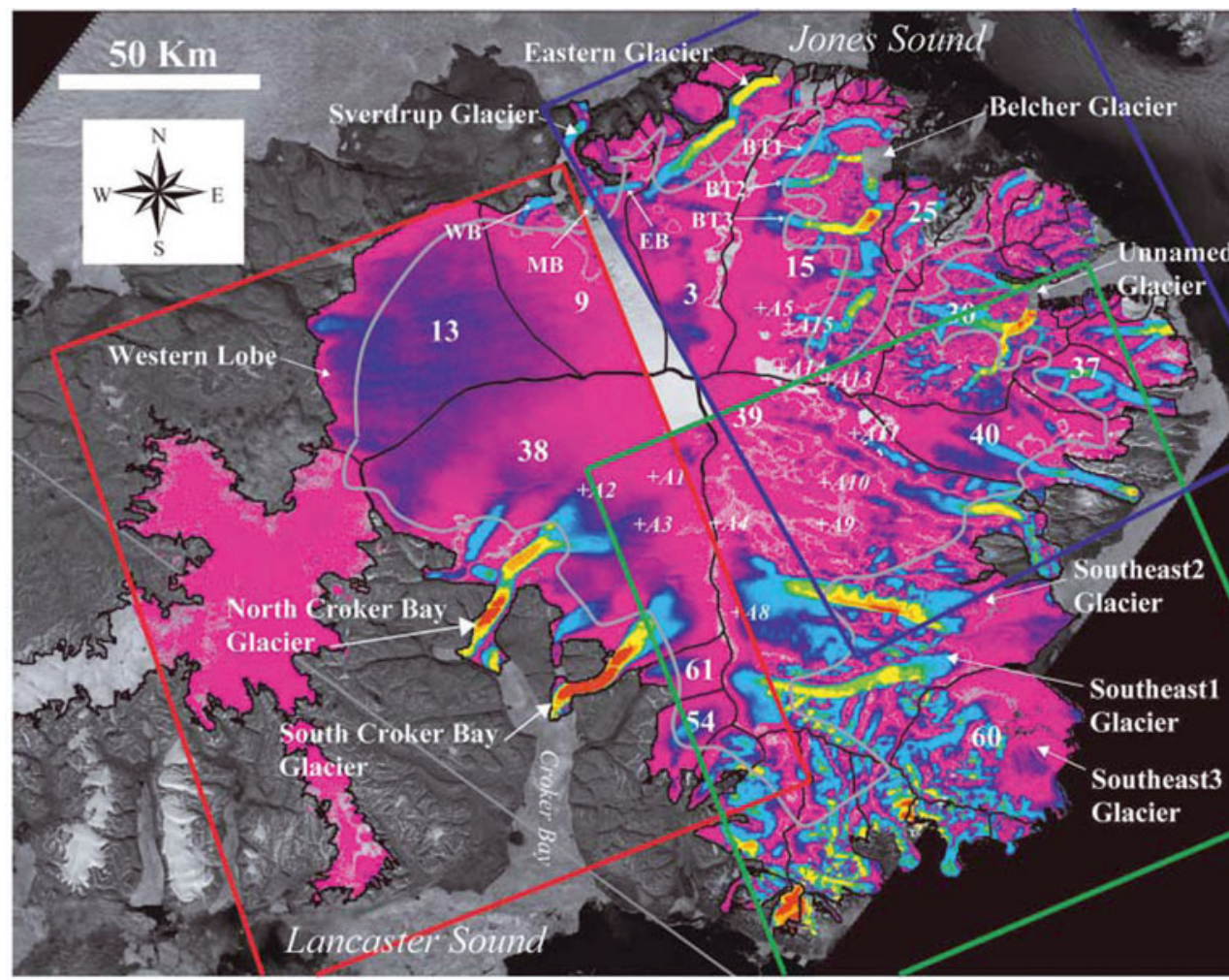

\begin{tabular}{clll}
\hline & Equilibrium line altitude & WB & West Branch \\
\cline { 1 - 1 } & Drainage basin boundary & MB & Main Branch \\
+ A2 & Basin ID & EB & East Branch \\
Gatellite look direction $\left(54^{\circ}\right)$ & BT1 & Belcher Tributary1 \\
& BT2 & Belcher Tributary2 \\
& BT3 & Belcher Tributary3
\end{tabular}

Look Direction Velocities $\left(\mathrm{m} \mathrm{a}^{-1}\right)$

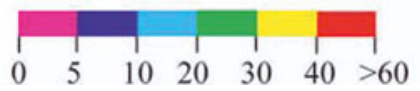

Fig. 9. Line-of-sight speeds (color) for Devon Ice Cap determined using ERS data plotted over an orthorectified Landsat 7 Enhanced Thematic Mapper Plus (ETM+) image (Burgess and others, 2005).

\section{FUTURE OUTLOOK}

The tremendous progress in glaciology that has been made with the existing and past international constellation of SARs is particularly remarkable in light of the fact that many were designed with no specific requirements for interferometry. Over the next decade, several more SAR satellites will be launched that will greatly improve our ability to monitor ice sheets and glaciers interferometrically. In 2012, ESA will launch the Sentinel-1 spacecraft that will collect C-band SAR data over ice sheets and glaciers from a 12 day repeat orbit, which will provide much better coherence than the 24 day repeat period of RADARSAT-1 and -2. Through 2014 and 2015, CSA will launch a constellation of three interferometrically capable C-band SARs, with each individual satellite in a 12 day repeat orbit but staggered so that collectively the three satellites provide a 4 day exact repeat cycle suitable for interferometry. In 2017, NASA is scheduled to launch the Deformation, Ecosystem Structure and Dynamics of Ice (DESDynl) mission, which consists of an L-band SAR optimized for interferometry and a five-beam lidar for vegetation and ice mapping. At L-band, the DESDynl 13 day repeat orbit is roughly equivalent in coherence to a 3 day repeat at C-band. JAXA is also planning to launch an Lband follow-on to its current ALOS instrument. Both the German and Italian space agencies have strong SAR programs that likely will produce follow-on missions to their respective TerraSAR-X and COSMO-SkyMed programs.
Because many of the new missions are optimized for InSAR, they also provide improved measurement capability. For example, larger volumes of data will allow improved averaging for better accuracy. As another example, DESDynl will collect data over most of the ice sheets from both ascending and descending orbits and from north- and southlooking geometries. Such data will allow the estimation of true 3-D displacements (Gray and others, 2005). The ability to look both right and left will also provide routine coverage over the entire Antarctic ice sheet, which many SARs now are incapable of acquiring or only rarely acquire.

While all these instruments should be capable of providing vast quantities of data suitable for ice-sheet and glacier studies, the scientific impact of these missions will be largely governed by the data distribution policies adopted by their respective space agencies. The DESDynl and Sentinel missions will have free and open data distribution, while the details of the data distribution for several other future missions remain to be resolved.

\section{SUMMARY}

InSAR techniques have revealed unanticipated behaviour of glaciers and ice sheets, which are among the most rapidly changing components of the Earth system, and, in the process, contributed to the transformation of glaciology from a data-poor to a data-rich discipline. Most notably, these 


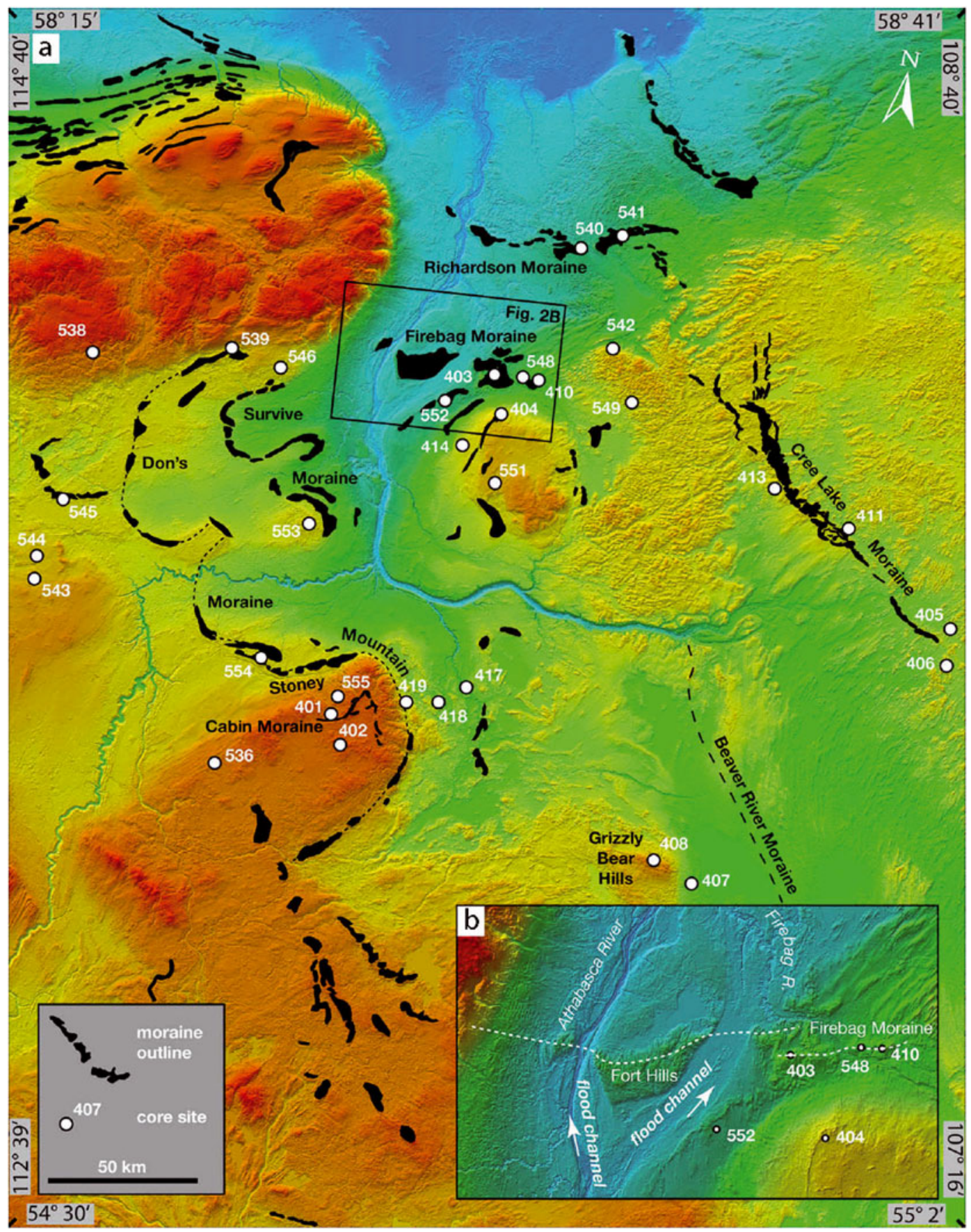

Fig. 10. (a) Moraines (black) many of which were mapped from analysis of the SRTM DEM (color) (Fisher and others, 2009). (b) Inset showing the area indicarted by a black rectangle in (a). Quaternary Science Reviews by Pergamon. Reproduced with permission of Pergamon via Copyright Clearance Center.

techniques and data have demonstrated that rather than responding to recent and present climate forcings very slowly, these vast frozen expanses are literally and figuratively much more dynamic than conventional wisdom had long held. InSAR has completely transformed our understanding of ice-sheet and glacier behaviour by revealing phenomena such as (a) the nearly instantaneous response to perturbations at outlet glacier termini, (b) the associated direct coupling between floating ice and grounded ice, (c) the extent of widespread seasonal acceleration in response to summer melt, (d) topographic and dynamic response to subglacial water movement, and (e) basal melting and accretion of floating ice. Moreover, in revealing the most dramatically varying aspect of ice-sheet and glacier mass balance - ice discharge - InSAR has contributed to the recognition that present ice-sheet models provide inadequate bounds on future sea level (Solomon and others, 2007). While InSAR has revealed limitations of state-of-theart ice-sheet models, it has also provided a wealth of data for modellers to use in developing and constraining the future models needed to project sea level with confidence. The broad range of InSAR-based glaciological accomplishments has largely been derived from data collected by instruments designed for other purposes. As a new generation of sensors is developed with specific design requirements for glacier and ice-sheet mapping, InSAR will provide an even richer set of observations that will continue to vastly improve our knowledge of many ice-sheet and glacier processes. 


\section{ACKNOWLEDGEMENTS}

The US National Science Foundation (NSF) funded the contributions by I.J. (ANT-0636719 and FY2011-025). The NASA Cryospheric Sciences Program funded B.S. (NNX09AE47G) and W.A. As the extensive reference list indicates, dozens of authors contributed to the results reviewed in this paper. We thank M. Maki for a careful proofreading of the manuscript. The final manuscript was improved by comments from $\mathrm{H}$. Fricker (scientific editor), L. Gray and an anonymous reviewer.

\section{REFERENCES}

Agassiz, L. 1967. Studies on glaciers preceded by the discourse of Neuchâtel. New York and London, Hafner Publishing Co.

Ahlstrøm, A.P., J.J. Mohr, N. Reeh, E.L. Christensen and R.LeB. Hooke. 2005. Controls on the basal water pressure in subglacial channels near the margin of the Greenland ice sheet. J. Glaciol., 51(174), 443-450.

Alley, R.B. and 7 others. 2008. A simple law for ice-shelf calving. Science, 322(5906), 1344.

Bamber, J.L., R.J. Hardy and I. Joughin. 2000a. An analysis of balance velocities over the Greenland ice sheet and comparison with synthetic aperture radar interferometry. J. Glaciol., 46(152), $67-74$.

Bamber, J.L., R.J. Hardy, P. Huybrechts and I. Joughin. 2000b. A comparison of balance velocities, measured velocities and thermomechanically modelled velocities for the Greenland ice sheet. Ann. Glaciol., 30, 211-216.

Bamber, J.L., D.G. Vaughan and I. Joughin. 2000c. Widespread complex flow in the interior of the Antarctic ice sheet. Science, 287(5456), 1248-1250.

Bamber, J.L. and 6 others. 2006. East Antarctic ice stream tributary underlain by major sedimentary basin. Geology, 34(1), 33-36.

Bell, R.E., M. Studinger, C.A. Shuman, M.A. Fahnestock and I. Joughin. 2007. Large subglacial lakes in East Antarctica at the onset of fast-flowing ice streams. Nature, 445(7130), 904-907.

Bougamont, M., S. Tulaczyk and I. Joughin. 2003a. Numerical investigations of the slow-down of Whillans Ice Stream, West Antarctica: is it shutting down like Ice Stream C? Ann. Glaciol., 37, 239-246.

Bougamont, M., S. Tulaczyk and I. Joughin. 2003b. Response of subglacial sediments to basal freeze-on: 2. Application in numerical modeling of the recent stoppage of Ice Stream C, West Antarctica. J. Geophys. Res., 108(B4), 2223. (10.1019/ 2002JB001936.)

Burgess, D.O., M.J. Sharp, D.W.F. Mair, J.A. Dowdeswell and T.J. Benham. 2005. Flow dynamics and iceberg calving rates of Devon Ice Cap, Nuvavut, Canada. J. Glaciol., 51(173), 219230.

Cheng, X. and G. Xu. 2006. The integration of JERS-1 and ERS SAR in differential interferometry for measurement of complex glacier motion. J. Glaciol., 52(176), 80-88.

Ciappa, A., L. Pietranera and F. Battazza. 2010. Perito Moreno Glacier (Argentina) flow estimation by COSMO SkyMed sequence of high-resolution SAR-X imagery. Remote Sens. Environ., 114(9), 2088-2096.

de Lange, R., A. Lucknam and T. Murray. 2007. Improvement of satellite radar feature tracking for ice velocity derivation by spatial frequency filtering. IEEE Trans. Geosci. Remote Sens., 45(7), 2309-2318.

Fahnestock, M.A., I. Joughin, T.A. Scambos, R. Kwok, W.B. Krabill and S. Gogineni. 2001. Ice-stream-related patterns of ice flow in the interior of northeast Greenland. J. Geophys. Res., 106(D24), 34,035-34,045.

Farr, T.G. and 17 others. 2007. The Shuttle Radar Topography Mission. Rev. Geophys., 45(2), RG2004. (10.1029/ 2005RG000183.)
Fatland, D.R. 1997. Cover SAR interferogram of Bagley Ice Field. Int. J. Remote Sens., 18(1), 3-4.

Fatland, D.R. and C.S. Lingle. 1998. Analysis of the 1993-95 Bering Glacier (Alaska) surge using differential SAR interferometry. J. Glaciol., 44(148), 532-546.

Fatland, D.R. and C.S. Lingle. 2002. InSAR observations of the 1993-95 Bering Glacier (Alaska, U.S.A.) surge and a surge hypothesis. J. Glaciol., 48(162), 439-451.

Fatland, D.R., C.S. Lingle and M. Truffer. 2003. A surface motion survey of Black Rapids Glacier, Alaska, U.S.A. Ann. Glaciol., 36 $29-36$.

Fischer, A., H. Rott and H. Björnsson. 2003. Observation of recent surges of Vatnajökull, Iceland, by means of ERS SAR interferometry. Ann. Glaciol., 37, 69-76.

Fisher, T.G., N. Waterson, T.V. Lowell and I. Hajdas. 2009. Deglaciation ages and meltwater routing in the Fort McMurray region, northeastern Alberta and northwestern Saskatchewan, Canada. Quat. Sci. Rev., 28(17-18), 1608-1624.

Ford, A.L.J., R.R. Forster and R.L. Bruhn. 2003. Ice surface velocity patterns on Seward Glacier, Alaska/Yukon, and their implications for regional tectonics in the Saint Elias Mountains. Ann. Glaciol., 36, 21-28.

Fricker, H.A., R. Coleman, L. Padman, T.A. Scambos, J. Bohlander and K.M. Brunt. 2009. Mapping the grounding zone of the Amery Ice Shelf, East Antarctica using InSAR, MODIS and ICESat. Antarct. Sci., 21(5), 515-532.

Gabriel, A.K. and R.M. Goldstein. 1988. Crossed orbit interferometry: theory and experimental results from SIR-B. Int. J. Remote Sens., 9(5), 857-872.

Gabriel, A.K., R.M. Goldstein and H.A. Zebker. 1989. Mapping small elevation changes over large areas: differential radar interferometry. J. Geophys. Res., 94(B7), 9183-9191.

Glasser, N.F. and K.N. Jansson. 2005. Fast-flowing outlet glaciers of the Last Glacial Maximum Patagonian Icefield. Quat. Res., 63(2), 206-211.

Glasser, N.F., K.N. Jansson, S. Harrison and J. Kleman. 2008. The glacial geomorphology and Pleistocene history of South America between $38^{\circ} \mathrm{S}$ and $56^{\circ}$ S. Quat. Sci. Rev., 27(3-4), 365-390.

Goldstein, R. 1995. Atmospheric limitations to repeat-track radar interferometry. Geophys. Res. Lett., 22(18), 2517-2520.

Goldstein, R.M., H.A. Zebker and C.L. Werner. 1988. Satellite radar interferometry: two-dimensional phase unwrapping. Radio Sci. 23(4), 713-720.

Goldstein, R.M., H. Engelhardt, B. Kamb and R.M. Frolich. 1993. Satellite radar interferometry for monitoring ice sheet motion: application to an Antarctic ice stream. Science, 262(5139), 1525-1530.

Graham, L.C. 1974. Synthetic interferometer radar for topographic mapping. IEEE Proc., 62(6), 763-768.

Gray, A.L., K.E. Mattar and P.W. Vachon. 1998. InSAR results from the RADARSAT Antarctic mapping mission data: estimation of data using a simple registration procedure. In Stein, T., ed. IGARSS '98. 18th International Geoscience and Remote Sensing Symposium, 6-10 July 1998, Seattle, Washington. Proceedings. Piscataway, NJ, Institute of Electrical and Electronics Engineers, $1638-1640$

Gray, A.L., K.E. Mattar and G. Sofko. 2000. Influence of ionospheric electron density fluctuations on satellite radar interferometry. Geophys. Res. Lett., 27(10), 1451-1454.

Gray, L. and 6 others. 2002. RADARSAT interferometry for Antarctic grounding-zone mapping. Ann. Glaciol., 34, 269-276.

Gray, L., I. Joughin, S. Tulaczyk, V.B. Spikes, R. Bindschadler and K. Jezek. 2005. Evidence for subglacial water transport in the West Antarctic Ice Sheet through three-dimensional satellite radar interferometry. Geophys. Res. Lett., 32(3), L03501. (10.1029/2004GL021387.)

Hoen, E.W. and H.A. Zebker. 2000. Penetration depths inferred from interferometric volume decorrelation observed over the Greenland ice sheet. IEEE Trans. Geosci. Remote Sens., 38(6), $2571-2583$. 
Howat, I.M., I. Joughin, S. Tulaczyk and S. Gogineni. 2005. Rapid retreat and acceleration of Helheim Glacier, east Greenland. Geophys. Res. Lett., 32(22), L22502. (10.1029/2005GL024737.)

Howat, I.M., I.R. Joughin and T.A. Scambos. 2007. Rapid changes in ice discharge from Greenland outlet glaciers. Science, 315(5818), 1559-1561.

Howat, I.M., I. Joughin, M. Fahnestock, B.E. Smith and T. Scambos. 2008. Synchronous retreat and acceleration of southeast Greenland outlet glaciers 2000-2006: ice dynamics and coupling to climate. J. Glaciol., 54(187), 646-660.

Hulbe, C.L., E. Rignot and D.R. MacAyeal. 1998. Comparison of ice-shelf creep flow simulations with ice-front motion of Filchner-Ronne Ice Shelf, Antarctica, detected by SAR interferometry. Ann. Glaciol., 27, 182-186.

Hulbe, C.L., I.R. Joughin, D.L. Morse and R.A. Bindschadler. 2000. Tributaries to West Antarctic ice streams: characteristics deduced from numerical modelling of ice flow. Ann. Glaciol., 31, 184-190.

Hulbe, C.L., W. Wang, I.R. Joughin and M.J. Siegert. 2003. The role of lateral and vertical shear in tributary flow toward a West Antarctic ice stream. Ann. Glaciol., 36, 244-250.

Hulbe, C.L., R. Johnston, I. Joughin and T. Scambos. 2005. Marine ice modification of fringing ice shelf flow. Arct. Antarct. Alp. Res., 37(3), 323-330.

Hulbe, C.L., C. Ledoux and K. Cruikshank. 2010. Propagation of long fractures in the Ronne Ice Shelf, Antarctica, investigated using a numerical model of fracture propagation. J. Glaciol., 56(197), 459-472.

Humbert, A., T. Kleiner, C.-O. Mohrholz, C. Oelke, R. Greve and M.A. Lange. 2009. A comparative modeling study of the Brunt Ice Shelf/Stancomb-Wills Ice Tongue system, East Antarctica. J. Glaciol., 55(189), 53-65.

Huybrechts, P. and J. de Wolde. 1999. The dynamic response of the Greenland and Antarctic ice sheets to multiple-century climatic warming. J. Climate, 12(8), 2169-2188.

Jacobs, S.S., H.H. Hellmer, C.S.M. Doake, A. Jenkins and R.M. Frolich. 1992. Melting of ice shelves and the mass balance of Antarctica. J. Glaciol., 38(130), 375-387.

Jenkins, A. and C.S.M. Doake. 1991. Ice-ocean interaction on Ronne Ice Shelf, Antarctica. J. Geophys. Res., 96(C1), 791-813.

Jezek, K.C. 1999. Glaciological properties of the Antarctic ice sheet from RADARSAT-1 synthetic aperture radar imagery. Ann. Glaciol., 29, 286-290.

Jezek, K.C., K. Farness, R. Carande, X. Wu and N. Labelle-Hamer. 2003. RADARSAT 1 synthetic aperture radar observations of Antarctica: Modified Antarctic Mapping Mission, 2000. Radio Sci., 38(4), 8067. (10.1029/2002RS002643.)

Joughin, I. 2002. Ice-sheet velocity mapping: a combined interferometric and speckle-tracking approach. Ann. Glaciol., 34, 195-201.

Joughin, I. 2010. Sensitivity of 21 st century sea level to oceaninduced thinning of Pine Island Glacier, Antarctica. Geophys. Res. Lett., 37(20), L20502. (10.1029/2010GL044819.)

Joughin, I. and J.L. Bamber. 2005. Thickening of the ice stream catchments feeding the Filchner-Ronne Ice Shelf, Antarctica. Geophys. Res. Lett., 32(17), L17503. (10.1029/2005GL023844.)

Joughin, I. and D.R. MacAyeal. 2005. Calving of large tabular icebergs from ice shelf rift systems. Geophys. Res. Lett., 32(2), L02501. (10.1029/2004GL020978.)

Joughin, I. and L. Padman. 2003. Melting and freezing beneath Filchner-Ronne Ice Shelf, Antarctica. Geophys. Res. Lett., 30(9), 1477-1480.

Joughin, I. and S. Tulaczyk. 2002. Positive mass balance of the Ross ice streams, West Antarctica. Science, 295(5554), 476-480.

Joughin, I. and D.G. Vaughan. 2004. Marine ice beneath the Filchner-Ronne Ice Shelf, Antarctica: a comparison of estimated thickness distributions. Ann. Glaciol., 39, 511-517.

Joughin, I.R., D.P. Winebrenner and M.A. Fahnestock. 1995. Observations of ice-sheet motion in Greenland using satellite radar interferometry. Geophys. Res. Lett., 22(5), 571-574.
Joughin, I., R. Kwok and M. Fahnestock. 1996a. Estimation of icesheet motion using satellite radar interferometry: method and error analysis with application to Humboldt Glacier, Greenland. J. Glaciol., 42(142), 564-575.

Joughin, I., D. Winebrenner, M. Fahnestock, R. Kwok and W. Krabill. 1996b. Measurement of ice-sheet topography using satellite-radar interferometry. J. Glaciol., 42(140), 10-22.

Joughin, I., S. Tulaczyk, M. Fahnestock and R. Kwok. 1996c. A mini-surge on the Ryder Glacier, Greenland, observed by satellite radar interferometry. Science, 274(5285), 228-230.

Joughin, I.R., R. Kwok and M.A. Fahnestock. 1998. Interferometric estimation of three-dimensional ice-flow using ascending and descending passes. IEEE Trans. Geosci. Remote Sens., 36(1), $25-37$.

Joughin, I., M. Fahnestock, R. Kwok, P. Gogineni and C. Allen. 1999a. Ice flow of Humboldt, Petermann and Ryder Gletscher, northern Greenland. J. Glaciol., 45(150), 231-241.

Joughin, I. and 7 others. 1999b. Tributaries of West Antarctic ice streams revealed by RADARSAT interferometry. Science, 286(5438), 283-286.

Joughin, I., M. Fahnestock, D. MacAyeal, J.L. Bamber and P. Gogineni. 2001. Observation and analysis of ice flow in the largest Greenland ice stream. J. Geophys. Res., 106(D24), 34,021-34,034.

Joughin, I., S. Tulaczyk, R.A. Bindschadler and S. Price. 2002. Changes in West Antarctic ice stream velocities: observation and analysis. J. Geophys. Res., 107(B11), 2289. (10.1029/ 2001JB001029.)

Joughin, I., E. Rignot, C.E. Rosanova, B.K. Lucchitta and J. Bohlander. 2003. Timing of recent accelerations of Pine Island Glacier, Antarctica. Geophys. Res. Lett., 30(13), 1706. (10.1029/ 2003GL017609.)

Joughin, I., D.R. MacAyeal and S. Tulaczyk. 2004a. Basal shear stress of the Ross ice streams from control method inversions. J. Geophys. Res., 109(B9), B09405. (10.1029/ 2003JB002960.)

Joughin, I., W. Abdalati and M.A. Fahnestock. 2004b. Large fluctuations in speed on Greenland's Jakobshavn Isbræ glacier. Nature, 432(7017), 608-610.

Joughin, I., S. Tulaczyk, D. MacAyeal and H. Engelhardt. 2004c. Melting and freezing beneath the Ross ice streams, Antarctica. J. Glaciol., 50(168), 96-108.

Joughin, I. and 10 others. 2005. Continued deceleration of Whillans Ice Stream, West Antarctica. Geophys. Res. Lett., 32(22), L22501. (10.1029/2005GL024319.).

Joughin, I., J.L. Bamber, T. Scambos, S. Tulaczyk, M. Fahnestock and D.R. MacAyeal. 2006. Integrating satellite observations with modelling: basal shear stress of the Filchner-Ronne ice streams, Antarctica. Philos. Trans. R. Soc. London, Ser. A, 364(1844), 1795-1814.

Joughin, I. and 7 others. 2008a. Continued evolution of Jakobshavn Isbræ following its rapid speedup. J. Geophys. Res., 113(F4), F04006. (10.1029/2008JF001023.)

Joughin, I., S.B. Das, M.A. King, B.E. Smith, I.M. Howat and T. Moon. 2008b. Seasonal speedup along the western flank of the Greenland Ice Sheet. Science, 320(5877), 781-783.

Joughin, I. and 6 others. 2009. Basal conditions for Pine Island and Thwaites Glaciers, West Antarctica, determined using satellite and airborne data. J. Glaciol., 55(190), 245-257.

Joughin, I., B.E. Smith, I.M. Howat, T. Scambos and T. Moon. 2010a. Greenland flow variability from ice-sheet-wide velocity mapping. J. Glaciol., 56(197), 415-430.

Joughin, I., B.E. Smith and D.M. Holland. 2010b. Sensitivity of $21 \mathrm{st}$ century sea level to ocean-induced thinning of Pine Island Glacier, Antarctica. Geophys. Res. Lett., 37(20), L20502. (10.1029/2010GL044819.)

Khazendar, A., E. Rignot and E. Larour. 2007. Larsen B Ice Shelf rheology preceding its disintegration inferred by a control method. Geophys. Res. Lett., 34(19), L19503. (10.1029/ 2007GL030980.) 
Khazendar, A., E. Rignot and E. Larour. 2009. Roles of marine ice, rheology, and fracture in the flow and stability of the Brunt/ Stancomb-Wills Ice Shelf. J. Geophys. Res., 114(F4), F04007. (10.1029/2008JF001124.)

Krabill, W. and 12 others. 2004. Greenland Ice Sheet: increased coastal thinning. Geophys. Res. Lett., 31(24), L24402. (10.1029/ 2004GL021533.)

Kwok, R. and M.A. Fahnestock. 1996. Ice sheet motion and topography from radar interferometry. IEEE Trans. Geosci. Remote Sens., 34(1), 189-200.

Kwok, R., M.J. Siegert and F.D. Carsey. 2000. Ice motion over Lake Vostok, Antarctica: constraints on inferences regarding the accreted ice. J. Glaciol., 46(155), 689-694.

Larour, E., E. Rignot and D. Aubry. 2004a. Modelling of rift propagation on Ronne Ice Shelf, Antarctica, and sensitivity to climate change. Geophys. Res. Lett., 31(16), L16404. (10.1029/ 2004GL020077.)

Larour, E., E. Rignot and D. Aubry. 2004b. Processes involved in the propagation of rifts near Hemmen Ice Rise, Ronne Ice Shelf, Antarctica. J. Glaciol., 50(170), 329-341.

Larour, E., E. Rignot, I. Joughin and D. Aubry. 2005. Rheology of the Ronne Ice Shelf, Antarctica, inferred from satellite radar interferometry data using an inverse control method. Geophys. Res. Lett., 32(5), L05503. (10.1029/2004GL021693.)

Legrésy, B., E. Rignot and I.E. Tabacco. 2000. Constraining ice dynamics at Dome C, Antarctica, using remotely sensed measurements. Geophys. Res. Lett., 27(21), 3493-3496.

Legrésy, B., A. Wendt, I.E. Tabacco, F. Rémy and R. Dietrich. 2004. Influence of tides and tidal current on Mertz Glacier, Antarctica. J. Glaciol., 50(170), 427-435.

Li, F.K. and R.M. Goldstein. 1990. Studies of multi-baseline spaceborne interferometric synthetic aperture radars. IEEE Trans. Geosci. Remote Sens., 28(1), 88-97.

Lowell, T.V., T.G. Fisher, I. Hajdas, K. Glover, H. Loope and T. Henry. 2009. Radiocarbon deglaciation chronology of the Thunder Bay, Ontario area and implications for ice sheet retreat patterns. Quat. Sci. Rev., 28(17-18), 1597-1607.

Lucchitta, B.K. and H.M. Ferguson. 1986. Antarctica: measuring glacier velocity from satellite images. Science, 234(4780), 1105-1108.

Luckman, A. and T. Murray. 2005. Seasonal variation in velocity before retreat of Jacobshavn Isbræ, Greenland. Geophys. Res. Lett., 32(8), L08501. (10.1029/2005GL022519.)

Luckman, A., T. Murray and T. Strozzi. 2002. Surface flow evolution throughout a glacier surge measured by satellite radar interferometry. Geophys. Res. Lett., 29(23), 2095. (10.1029/ 2001GL014570.)

Luckman, A., T. Murray, H. Jiskoot, H. Pritchard and T. Strozzi. 2003. ERS SAR feature-tracking measurement of outlet glacier velocities on a regional scale in East Greenland. Ann. Glaciol., 36, 129-134.

Luckman, A., T. Murray, R. de Lange and E. Hanna. 2006. Rapid and synchronous ice-dynamic changes in East Greenland. Geophys. Res. Lett., 33(3), L03503. (10.1029/2005GL025428.)

Luckman, A., D.J. Quincey and S. Bevan. 2007. The potential of satellite radar interferometry and feature tracking for monitoring flow rates of Himalayan glaciers. Remote Sens. Environ., 111(2-3), 172-181.

Luthcke, S.B. and 8 others. 2006. Recent Greenland ice mass loss by drainage system from satellite gravity observations. Science, 314(5803), 1286-1289.

MacAyeal, D.R. 1993. A tutorial on the use of control methods in ice-sheet modeling. J. Glaciol., 39(131), 91-98.

MacAyeal, D.R., R.A. Bindschadler and T.A. Scambos. 1995. Basal friction of Ice Stream E, West Antarctica. J. Glaciol., 41(138), 247-262.

Magnússon, E., H. Rott, H. Björnsson and F. Pálsson. 2007. The impact of jökulhlaups on basal sliding observed by SAR interferometry on Vatnajökull, Iceland. J. Glaciol., 53(181), 232-240.
Magnússon, E., H. Björnsson, H. Rott and F. Pálsson. 2010. Reduced glacier sliding caused by persistent drainage from a subglacial lake. Cryosphere, 4(1), 13-20.

Massonnet, D. and K.L. Feigl. 1998. Radar interferometry and its application to changes in the Earth's surface. Rev. Geophys., 36(4), 441-500.

Mattar, K.E., P.W. Vachon, D. Geudtner, A.L. Gray, I.G. Cumming and M. Brugman. 1998. Validation of alpine glacier velocity measurements using ERS tandem-mission SAR data. IEEE Trans. Geosci. Remote Sens., 36(3), 974-984.

Mercer, J.H. 1978. West Antarctic ice sheet and $\mathrm{CO}_{2}$ greenhouse effect: a threat of disaster. Nature, 271(5643), 321-325.

Michel, R. and E. Rignot. 1999. Flow of Glaciar Moreno, Argentina, from repeat-pass Shuttle Imaging Radar images: comparison of the phase correlation method with radar interferometry. J. Glaciol., 45(149), 93-100.

Mohr, J.J., N. Reeh and S.N. Madsen. 1998. Three-dimensional glacial flow and surface elevation measured with radar interferometry. Nature, 391(6664), 273-276.

Morlighem, M., E. Rignot, H. Seroussi, E. Larour, H. Ben Dhia and D. Aubry. 2010. Spatial patterns of basal drag inferred using control methods from a full-Stokes and simpler models for Pine Island Glacier, West Antarctica. Geophys. Res. Lett., 37(14), L14502. (10.1029/2010GL043853.)

Murray, T., T. Strozzi, A. Luckman, H. Pritchard and H. Jiskoot. 2002. Ice dynamics during a surge of Sortebræ, East Greenland. Ann. Glaciol., 34, 323-329.

Murray, T., A. Luckman, T. Strozzi and A.-M. Nuttall. 2003. The initiation of glacier surging at Fridtjovbreen, Svalbard. Ann. Glaciol., 36, 110-116.

Muskett, R.R., C.S. Lingle, J.M. Sauber, B.T. Rabus and W.V. Tangborn. 2008a. Acceleration of surface lowering on the tidewater glaciers of Icy Bay, Alaska, U.S.A. from InSAR DEMs and ICESat altimetry. Earth Planet. Sci. Lett., 265(3-4), 345-359.

Muskett, R.R., C.S. Lingle, J.M. Sauber, A.S. Post, W.V. Tangborn and B.T. Rabus. 2008b. Surging, accelerating surface lowering and volume reduction of the Malaspina Glacier system, Alaska, USA, and Yukon, Canada, from 1972 to 2006. J. Glaciol., 54(188), 788-800.

Muskett, R.R. and 6 others. 2009. Airborne and spaceborne DEMand laser altimetry-derived surface elevation and volume changes of the Bering Glacier system, Alaska, USA, and Yukon, Canada, 1972-2006. J. Glaciol., 55(190), 316-326.

Nick, F.M., A. Vieli, I.M. Howat and I. Joughin. 2009. Large-scale changes in Greenland outlet glacier dynamics triggered at the terminus. Nature Geosci., 2(2), 110-114.

O'Cofaigh, C., D.J.A. Evans and I.R. Smith. 2010. Large-scale reorganization and sedimentation of terrestrial ice streams during late Wisconsinan Laurentide Ice Sheet deglaciation. Geol. Soc. Am. Bull., 122(5-6), 743-756.

Palmer, S., A. Shepherd, H. Björnsson and F. Pálsson. 2009. Ice velocity measurements of Langjökull, Iceland, from interferometric synthetic aperture radar (InSAR). J. Glaciol., 55(193), 834-838.

Paterson, W.S.B. 1994. The physics of glaciers. Third edition. Oxford, etc., Elsevier.

Pattyn, F. and D. Derauw. 2002. Ice-dynamic conditions of Shirase Glacier, Antarctica, inferred from ERS SAR interferometry. J. Glaciol., 48(163), 559-565.

Payne, A.J., A. Vieli, A. Shepherd, D.J. Wingham and E. Rignot. 2004. Recent dramatic thinning of largest West Antarctic ice stream triggered by oceans. Geophys. Res. Lett., 31(23), L23401. (10.1029/2004GL021284.)

Price, S.F., R.A. Bindschadler, C.L. Hulbe and I.R. Joughin. 2001. Post-stagnation behavior in the upstream regions of Ice Stream C, West Antarctica. J. Glaciol., 47(157), 283-294.

Pritchard, H., T. Murray, T. Strozzi, S. Barr and A. Luckman. 2003. Surge-related topographic change of the glacier Sortebræ, East 
Greenland, derived from synthetic aperture radar interferometry. J. Glaciol., 49(166), 381-390.

Pritchard, H., T. Murray, A. Luckman, T. Strozzi and S. Barr. 2005. Glacier surge dynamics of Sortebræ, east Greenland, from synthetic aperture radar feature tracking. J. Geophys. Res., 110(F3), F03005. (10.1029/2004JF000233.)

Pritchard, H.D., R.J. Arthern, D.G. Vaughan and L.A. Edwards. 2009. Extensive dynamic thinning on the margins of the Greenland and Antarctic ice sheets. Nature, 461(7266), 971-975.

Rabus, B.T. and D.R. Fatland. 2000. Comparison of SAR-interferometric and surveyed velocities on a mountain glacier: Black Rapids Glacier, Alaska, U.S.A. J. Glaciol., 46(152), 119-128.

Rabus, B.T. and O. Lang. 2002. On the representation of ice-shelf grounding zones in SAR interferograms. J. Glaciol., 48(162), 345-356.

Rabus, B.T., O. Lang and U. Adolphs. 2003. Interannual velocity variations and recent calving of Thwaites Glacier Tongue, West Antarctica. Ann. Glaciol., 36, 215-224.

Reeh, N., S.N. Madsen and J.J. Mohr. 1999. Combining SAR interferometry and the equation of continuity to estimate the three-dimensional glacier surface-velocity vector. J. Glaciol., 45(151), 533-538.

Reeh, N., J.J. Mohr, S.N. Madsen, H. Oerter and N.S. Gundestrup. 2003. Three-dimensional surface velocities of Storstrømmen glacier, Greenland, derived from radar interferometry and ice-sounding radar measurements. J. Glaciol., 49(165), 201-209.

Retzlaff, R. and C.R. Bentley. 1993. Timing of stagnation of Ice Stream C, West Antarctica, from short-pulse radar studies of buried surface crevasses. J. Glaciol., 39(133), 553-561.

Rignot, E. 1996. Tidal motion, ice velocity and melt rate of Petermann Gletscher, Greenland, measured from radar interferometry. J. Glaciol., 42(142), 476-485.

Rignot, E.J. 1998a. Fast recession of a West Antarctic glacier. Science, 281(5376), 549-551.

Rignot, E. 1998b. Hinge-line migration of Petermann Gletscher, north Greenland, detected using satellite-radar interferometry. J. Glaciol., 44(148), 469-476.

Rignot, E. 1998c. Radar interferometry detection of hinge-line migration on Rutford Ice Stream and Carlson Inlet, Antarctica. Ann. Glaciol., 27, 25-32.

Rignot, E.J.M. 2000. Effect of Faraday rotation on L-band interferometric and polarimetric synthetic-aperture-radar data. IEEE Trans. Geosci. Remote Sens., 38(1), 383-390,

Rignot, E. 2001. Evidence for rapid retreat and mass loss of Thwaites Glacier, West Antarctica. J. Glaciol., 47(157), 213-222.

Rignot, E. 2002. Mass balance of East Antarctic glaciers and ice shelves from satellite data. Ann. Glaciol., 34, 217-227.

Rignot, E. 2006. Changes in ice dynamics and mass balance of the Antarctic ice sheet. Philos. Trans. R. Soc. London, Ser. A, 364(1844), 1637-1655.

Rignot, E. 2008. Changes in West Antarctic ice stream dynamics observed with ALOS PALSAR data. Geophys. Res. Lett., 35(12), L12505. (10.1029/2008GL033365.)

Rignot, E. and S.S. Jacobs. 2002. Rapid bottom melting widespread near Antarctic ice sheet grounding lines. Science, 296(5575), 2020-2023.

Rignot, E. and P. Kanagaratnam. 2006. Changes in the velocity structure of the Greenland Ice Sheet. Science, 311(5673), 986-990.

Rignot, E. and K. Steffen. 2008. Channelized bottom melting and stability of floating ice shelves. Geophys. Res. Lett., 35(2), L02503. (10.1029/2007GL031765.)

Rignot, E. and R.H. Thomas. 2002. Mass balance of polar ice sheets. Science, 297(5586), 1502-1506.

Rignot, E., K.C. Jezek and H.G. Sohn. 1995. Ice flow dynamics of the Greenland ice sheet from SAR interferometry. Geophys. Res. Lett., 22(5), 575-578.
Rignot, E.J., S.P. Gogineni, W.B. Krabill and S. Ekholm. 1997. North and north-east Greenland ice discharge from satellite radar interferometry. Science, 276(5314), 934-937.

Rignot, E., G. Buscarlet, B. Csathó, S. Gogineni, W. Krabill and M. Schmeltz. 2000a. Mass balance of the northeast sector of the Greenland ice sheet: a remote-sensing perspective. J. Glaciol., 46(153), 265-273.

Rignot, E., L. Padman, D.R. MacAyeal and M. Schmeltz. $2000 \mathrm{~b}$. Observation of ocean tides below the Filchner and Ronne Ice Shelves, Antarctica, using synthetic aperture radar interferometry: comparison with tide model predictions. J. Geophys. Res., 105(C8), 19,615-19,630.

Rignot, E., S. Gogineni, I. Joughin and W. Krabill. 2001 a. Contribution to the glaciology of northern Greenland from satellite radar interferometry. J. Geophys. Res., 106(D24), 34,007-34,019.

Rignot, E., K. Echelmeyer and W. Krabill. 2001b. Penetration depth of interferometric synthetic-aperture radar signals in snow and ice. Geophys. Res. Lett., 28(18), 3501-3504.

Rignot, E., D.G. Vaughan, M. Schmeltz, T. Dupont and D. MacAyeal. 2002. Acceleration of Pine Island and Thwaites Glaciers, West Antarctica. Ann. Glaciol., 34, 189-194.

Rignot, E., A. Rivera and G. Casassa. 2003. Contribution of the Patagonian icefields of South America to sea level rise. Science, 302(5644), 434-437.

Rignot, E., G. Casassa, P. Gogineni, W. Krabill, A. Rivera and R. Thomas. 2004a. Accelerated ice discharge from the Antarctic Peninsula following the collapse of Larsen B ice shelf. Geophys. Res. Lett., 31(18), L18401. (10.1029/2004GL020697.)

Rignot, E., D. Braaten, P. Gogineni, W.B. Krabill and J.R. McConnell. 2004b. Rapid ice discharge from southeast Greenland glaciers. Geophys. Res. Lett., 31(10), L10401. (10.1029/2004GL019474.)

Rignot, E. and 9 others. 2005. Recent ice loss from the Fleming and other glaciers, Wordie Bay, West Antarctic Peninsula. Geophys. Res. Lett., 32(7), L07502. (10.1029/2004GL021947.)

Rignot, E., J.E. Box, E. Burgess and E. Hanna. 2008a. Mass balance of the Greenland ice sheet from 1958 to 2007. Geophys. Res. Lett., 35(20), L20502. (10.1029/2008GL035417.)

Rignot, E. and 6 others. 2008b. Recent Antarctic ice mass loss from radar interferometry and regional climate modelling. Nature Geosci., 1(2), 106-110.

Rosen, P.A. and 6 others. 2000. Synthetic aperture radar interferometry. IEEE Proc., 88(3), 333-385.

Rott, H. 2009. Advances in interferometric synthetic aperture radar (InSAR) in earth system science. Progr. Phys. Geogr., 33(6), 769-791.

Rott, H., M. Stuefer, A. Siegel, P. Skvarca and A. Eckstaller. 1998. Mass fluxes and dynamics of Moreno Glacier, Southern Patagonia Icefield. Geophys. Res. Lett., 25(9), 1407-1410.

Rott, H., W. Rack, P. Skvarca and H. De Angelis. 2002. Northern Larsen Ice Shelf, Antarctica: further retreat after collapse. Ann. Glaciol., 34, 277-282.

Rott, H., F. Müller, T. Nagler and D. Floricioiu. 2010. The imbalance of glaciers after disintegration of Larsen B ice shelf, Antarctic Peninsula. Cryos. Discuss., 4(3), 1607-1633.

Scambos, T.A., J.A. Bohlander, C.A. Shuman and P. Skvarca. 2004. Glacier acceleration and thinning after ice shelf collapse in the Larsen B embayment, Antarctica. Geophys. Res. Lett., 31(18), L18402. (10.1029/2004GL020670.)

Schmeltz, M., E. Rignot and D.R. MacAyeal. 2001. Ephemeral grounding as a signal of ice-shelf change. J. Glaciol., 47(156), $71-77$.

Schmeltz, M., E. Rignot, T.K. Dupont and D.R. MacAyeal. 2002a. Sensitivity of Pine Island Glacier, West Antarctica, to changes in ice-shelf and basal conditions: a model study. J. Glaciol., 48(163), 552-558.

Schmeltz, M., E. Rignot and D. MacAyeal. 2002b. Tidal flexure along ice-sheet margins: comparison of InSAR with an elasticplate model. Ann. Glaciol., 34, 202-208. 
Shabtaie, S. and C.R. Bentley. 1987. West Antarctic ice streams draining into the Ross Ice Shelf: configuration and mass balance. J. Geophys. Res., 92(B2), 1311-1336.

Shaw, J., D. Sharpe and J. Harris. 2010. A flowline map of glaciated Canada based on remote sensing data. Can. J. Earth Sci., 47(1), 89-101.

Shepherd, A., D. Wingham and J.A. Mansley. 2002. Inland thinning of the Amundsen Sea sector, West Antarctica. Geophys. Res. Lett., 29(10), 1364. (10.1029/2001GL014183.)

Shepherd, A., A. Hubbard, P. Nienow, M. McMillan and I. Joughin. 2009. Greenland ice sheet motion coupled with daily melting in late summer. Geophys. Res. Lett., 36(1), L01501. (10.1029/ 2008GL035758.)

Short, N.H. and A.L. Gray. 2004. Potential for RADARSAT-2 interferometry: glacier monitoring using speckle tracking. Can. J. Remote Sens., 30(3), 504-509.

Short, N.H. and A.L. Gray. 2005. Glacier dynamics in the Canadian High Arctic from RADARSAT-1 speckle tracking. Can. J. Remote Sens., 31(3), 225-239.

Siegert, M.J., A.J. Payne and I. Joughin. 2003. Spatial stability of Ice Stream D and its tributaries, West Antarctica, revealed by radioecho sounding and interferometry. Ann. Glaciol., 37, 377-382.

Siegert, M.J. and 7 others. 2004. Subglacial Lake Ellsworth: a candidate for in situ exploration in West Antarctica. Geophys. Res. Lett., 31(23), L23403. (10.1029/2004GL021477.)

Solomon, S. and 7 others, eds. 2007. Climate change 2007: the physical science basis. Contribution of Working Group I to the Fourth Assessment Report of the Intergovernmental Panel on Climate Change. Cambridge, etc., Cambridge University Press.

Stearns, L.A., K.C. Jezek and C.J. van der Veen. 2005. Decadalscale variations in ice flow along Whillans Ice Stream and its tributaries, West Antarctica. J. Glaciol., 51(172), 147-157.

Strozzi, T., A. Luckman, T. Murray, U. Wegmuller and C.L. Werner. 2002. Glacier motion estimation using satellite-radar offsettracking procedures. IEEE Trans. Geosci. Remote Sens., 40(11), 2834-2391.

Sykes, H.J., T. Murray and A. Luckman. 2009. The location of the grounding zone of the Evans Ice Stream, Antarctica, investigated using SAR interferometry and modelling. Ann. Glaciol., 50(52), 35-40.

Thomas, R.H. and 8 others. 2000. Substantial thinning of a major east Greenland outlet glacier. Geophys. Res. Lett., 27(9), 1291-1294.

Thomas, R.H., E.J. Rignot, K. Kanagaratnam, W.B. Krabill and G. Casassa. 2004. Force-perturbation analysis of Pine Island Glacier, Antarctica, suggests cause for recent acceleration. Ann. Glaciol., 39, 133-138.

Thorsteinsson, T., C.F. Raymond, G.H. Gudmundsson, R.A. Bindschadler, P. Vornberger and I. Joughin. 2003. Bed topography and lubrication inferred from surface measurements on fastflowing ice streams. J. Glaciol., 49(167), 481-490.

VanLooy, J.A. and R.R. Forster. 2008. Glacial changes of five southwest British Columbia icefields, Canada, mid-1980s to 1999. J. Glaciol., 54(186), 469-478.

Velicogna, I. and J. Wahr. 2006. Measurements of time-variable gravity show mass loss in Antarctica. Science, 311(5768), 1754-1756.

Vieli, A., A.J. Payne, Z. Du and A. Shepherd. 2006. Numerical modelling and data assimilation of the Larsen $B$ ice shelf, Antarctic Peninsula. Philos. Trans. R. Soc. London, Ser. A, 364(1844), 1815-1839.

Vieli, A., A.J. Payne, A. Shepherd and Z. Du. 2007. Causes of precollapse changes of the Larsen B ice shelf: numerical modelling and assimilation of satellite observations. Earth Planet. Sci. Lett., 259(3-4), 297-306.

Vogel, S.W., S. Tulaczyk and I.R. Joughin. 2003. Distribution of basal melting and freezing beneath tributaries of Ice Stream C: implication for the Holocene decay of the West Antarctic ice sheet. Ann. Glaciol., 36, 273-282.

Wang, W., H.J. Zwally, C.L. Hulbe, M.J. Siegert and I. Joughin. 2003. Anisotropic ice flow leading to the onset of Ice Stream D, West Antarctica: numerical modelling based on the observations from Byrd Station borehole. Ann. Glaciol., 37, 397-403.

Wen, J., K.C. Jezek, B. Csathó, U.C. Herzfeld, K.L. Farness and P. Huybrechts. 2007. Mass budgets of the Lambert, Mellor and Fisher Glaciers and basal fluxes beneath their flowbands on Amery Ice Shelf. Sci. China D, 50(11), 1693-1706.

Whillans, I.M. 1987. Force budget of ice sheets. In Van der Veen, C.J. and J. Oerlemans, eds. Dynamics of the West Antarctic ice sheet. Dordrecht, etc., D. Reidel Publishing Co., 17-36.

Whillans, I.M. and C.J. van der Veen. 1993. New and improved determinations of velocity of Ice Streams B and C, West Antarctica. J. Glaciol., 39(133), 483-490.

Wingham, D.J., M.J. Siegert, A. Shepherd and A.S. Muir. 2006. Rapid discharge connects Antarctic subglacial lakes. Nature, 440(7087), 1033-1036

Young, N.W. and G. Hyland. 2002. Velocity and strain rates derived from InSAR analysis over the Amery Ice Shelf, East Antarctica. Ann. Glaciol., 34, 228-234.

Zebker, H.A. and R.M. Goldstein. 1986. Topographic mapping from interferometric synthetic aperture radar observations. J. Geophys. Res., 91(B5), 4993-4999.

Zwally, H.J., W. Abdalati, T. Herring, K. Larson, J. Saba and K. Steffen. 2002. Surface melt-induced acceleration of Greenland ice-sheet flow. Science, 297(5579), 218-222.

Zwally, H.J. and 7 others. 2005. Mass changes of the Greenland and Antarctic ice sheets and shelves and contributions to sealevel rise: 1992-2002. J. Glaciol., 51(175), 509-527. 